\title{
Built environment, creativity, social art: The recovery of public space as engine of human development
}

\author{
Anna Onesti ${ }^{1}$ \\ ${ }^{1}$ University of Napoli Federico II, Naples, Italy \\ Received: 11 September 2016/Accepted: 5 September 2017
}

\begin{abstract}
The paper is a part of a comprehensive research aimed at operationalizing HUL approach and experimenting it in the buffer zone of Pompei, mainly in Torre Annunziata (Italy), and is based on the recognition of art and cultural heritage as tools for "managing the change" of landscape. The proposed thesis is that the recovery of public space, configured by art and culture and shared with local community according to an inclusive approach, contribute to regenerate creativity, reconstructing the relationships between people, communities and landscape. This lays the foundations for a "creative environment" and regenerative, concived as a prerequisite of development. In this process, art is a driver which acts on the creativity of local residents, stimulating their critical thinking, open-mindedness and design capacity, and leading them to accept diversity as an opportunity. Focusing on theories and on the empirical analysis of a best practice, MAAM Museum in Rome, this paper has three main objectives: to produce empirical evidence on the relationship between art, heritage and community relationships; to make transferable and replicable in other contexts, such as Torre Annunziata, the process experienced at MAAM; to develop a methodology able to soliciting, integrating and supporting the regeneration of relationships in the town of Torre Annunziata.
\end{abstract}

\section{Introduction}

Population growth and migration, climate change and energy resources, economic crisis and social inequality, cultural globalization and rapid growth of ICTs are global processes affecting both people and places. The "New Urban World" (Nijkamp, Kourtit 2012) calls for a deeper reflection on the strategies to implement, by acting locally, with the aim of safeguarding and promoting human wellbeing and human dimension of development. As UNESCO recommendation pointed out, "Urban growth is transforming the essence of many historic urban areas. Global processes have a deep impact on the values attributed by communities to urban areas and their settings, and on the perception and realities of their inhabitants and users" (UNESCO 2011, art. 17).

Despite the inability of many local policies to face new global challenges, all around the world there is an increasing number of bottom-up experiences in which artistic practices activate the change in degraded or abandoned spaces and urban areas, giving shape to new urban landscapes. Slums, abandoned factories, degraded public spaces, historical centers become a testing ground for new forms of synergies between different actors, artists, foundations, cultural associations, third sector organizations, professionals and citizens. From street art to site-specific installations, from poetry to theater up to "live" works, artistic experience, shared with local communities, become instrument to regenerate both 
the system of relations between people, which supports the definition of community, and the process of interaction between people and built environment. New forms of patronage, alternative to the public, are emerging and new institutions, legal bodies, associations and foundations arise in order to manage the process of change. Spread throughout the world, these practices are shaping a 'geography of change' (Fondazione Pistoletto 2003), in which art is an instrument of investigation, understanding and change of reality.

It is not just the empirical evidence which underlines the "social" function of art and cultural heritage. By the Faro Convention (Council of Europe 2005b), the European Community recognized that cultural heritage is the fundamental element that characterizes and holds together a community. Through the notion of heritage community (Article $2 \mathrm{~b}$ ), Faro Convention demonstrates that "by valuing and wishing to pass on specific aspects of the cultural heritage, in interaction with others, an individual becomes part of a community" (Council of Europe 2005a, art. 2). Consistent with the focus definitively on people and "their constantly evolving values, beliefs, knowledge and traditions" (Council of Europe 2005b, art. 2, paragraph a), cultural heritage assumes the widest possible sense, as it can be intended "as a continuing process, of creating, constructing, using and changing heritage" (Fairclough et al. 2014, p. 11). In this framework, promoting cultural heritage protection is a "central factor in mutually supporting objectives of sustainable development, cultural diversity and contemporary creativity" (Council of Europe 2005b, art. 5, paragraph e).

Supporting the principles introduced by Faro Convention, UNESCO Recommendations on Historic Urban Landscape (UNESCO 2011) interpret conservation as a strategy to achieve a balance between urban growth and life quality on a sustainable basis (art. 3) and consider cultural diversity and creativity as key assets for human, social and economic development (art. 12). The definition of tools to implement HUL approach, prompted by UNESCO (2011, art. 24), becomes crucial not only in order to protect the landscape, but above all to build a new "human" development on a local basis, which is consistent with new Millennium goals (United Nations 2015). Operationalizing HUL approach means, therefore, to contribute to achieve the United Nations Sustainable Development Goals and, in particular, the "urban" one (Goal 11) and to make "inclusive, secure, resilient and sustainable cities" (Fusco Girard 2014).

The paper is part of a comprehensive research aimed at operationalizing the HUL approach and experimenting it in the buffer zone of Pompei, mainly in Torre Annunziata (Italy) (Fusco Girard et al. 2016) and focuses on the contribution of art and cultural heritage for "managing the change" of landscape. The proposed thesis is that the recovery of public space, configured by art and culture and shared with local community according to an inclusive approach, contributes to regenerate creativity, reconstructing the relationships between people, communities and landscape. This lays the foundations for a "creative environment" (Törnqvist 1983, Santagata 2009) and regenerative (Fusco Girard 2014), conceived as a prerequisite for development. In this process, art is a driver which acts on the creativity of local residents, stimulating their critical thinking, open-mindedness and design capacity, and leading them to accept diversity as an opportunity.

Focusing on theories and on the empirical analysis of a best practice, such as MAAM Museum in Rome, this paper has three main objectives: to produce empirical evidence on the relationships between art, heritage and community; to make transferable and replicable in other context, such as Torre Annunziata, the process experienced at MAAM; to develop a methodology able to soliciting, integrating and supporting the regeneration of relationships in the town of Torre Annunziata.

\section{The beauty of HUL}

HUL approach introduces the "principle of relationality" (Fusco Girard 2013) as a new holistic and integrated vision, which links tradition and modernity, past and present, present and future in a systemic/circular and synergistic perspective of development, centered on human beings. This approach outlines a new cultural perspective for urban initiatives, which enhances relationships and interdependencies between the different aspects and the whole and compares universal values and local identities (D'Auria, Pugliese 
2013). The historic urban landscape, "world of men and things", can be interpreted as a complex adaptive system with two interacting subsystems: built environment (Ciribini 1979) and heritage community (Council of Europe 2005b). Communities act on built environment through a sedimented intangible cultural capital, making use of and enhancing local resources. In turn, built environment causes relational impacts on communities, regenerating both social ties and their relationships with environment.

This link between cultural production, daily needs and behaviours of people is very strong in Italy: for describing the intangible cultural capital of the community we just say "cultura materiale" ("material" culture), whereas other countries use the term "intangible", focusing more on non-material dimensions (Cuccia, Santagata 2003). Built environment is the tangible expression par excellence of the communities that have shaped it. It reveals in material forms the system of values, exhibiting the processes that, over time, shaped it (Bouchenaki 2003): to meet their needs and to adapt the performance of built heritage - local communities continuously change the landscape (Fontana 2012, Viola 2012), choosing what to preserve and what to change, in a dynamic equilibrium between past and future (Caterina 2012). At the same time, communities are shaped by the built environment which, through its spatial organization and its relationship with nature and climate, defined their structural attributes, influencing the behavior of both individuals and community. The reciprocal interaction between places and communities has produced long-lasting co-evolutionary dynamics (Magnaghi 2012), which in turn created the extraordinary diversity of Italian landscapes. The "co-evolutionary" relationship between community and built environment and the relationship between place and community are both elective relationships of care, feeding, maintenance and culture-expressive: people belong to a territory as they belong to a culture . There can be no landscape without a cultural perspective, allowing the harmonious coexistence of different elements, also very distant in time (Bonesio 2012). As landscape is the creation of a community as a whole, its conservation is related to the reconstruction of community and it is an essential element of local self-sustainable development (Magnaghi 2010).

\subsection{The meaning of beauty}

"Beauty" has been defined as the set of attributes which man enjoys without desiring to possess them (Eco 2005), going beyond daily needs to express the making of sense and avoiding the fear of passing (Givone 2012). These attributes of beauty makes it ontologically a "common ownership" good which everyone should use without any exclusive claim (Rodotà 2012).

Beauty is not a mere embellishment of reality, but a structural data, which comes from the diversity and plurality of interconnected elements (Fusco Girard 1989). The beauty of landscape derives from the synthesis of different dimensions. Communicating that some criteria/attributes are satisfied at the highest levels, and each element is interconnected to the other, the landscape transfers a sense of wholeness, of fulfillment. In this sense, beauty becomes the main indicator of "proper functioning" of landscape as a complex ecosystem: in the case of a natural landscape, beauty refers to the perfect functioning of the ecosystem, in the case of a built landscape, it shows the link between place and communities, the harmony between nature and man (Fusco Girard, Nijkamp 2005).

A significant contribution to a definition of complex beauty is owed to the theories of the philosopher Arnold Berleant, who pointed out that the loss of human scale in the cities have an aesthetic character, in a sense not limited to visual aspects. As beauty has a synesthetic character, negations of beauty are not only in the transformations which invasively modify scenes and urban views, but also in traffic flows that invade the cities (aesthetic intrusion), in the presence of excessive sound and color (aesthetic distortion), in poor quality of living (aesthetic deprivation), linked to bad sunlight exposure, in unrestrained lifestyle, in the excess of food and consumption (aesthetic depravity). Adopting Schiller's theory (1794 in Berleant 2004) who places the aesthetic experience at the basis of morality, Berleant sees beauty as a source, a sign and a standard of human value. For changing landscape, it is necessary an aesthetic knowledge, meaning the ability to perceive landscape through all the senses, a kind of re-creation, that implies the need to retrace the creative process generating the element which we enjoy (Berleant 
2004). Whereas, landscape acts on humans as a field of forces, which establishes an absolute reciprocity relation, so that the user is an integral part of it.

The influence of beauty in physical regeneration, moral and spiritual landscapes and sites have been explicitly recognized by UNESCO since 1962. Beauty contributes to the cultural and artistic life of people but must be harmonized with the needs of communities, their evolution and the rapid development of technical progress (UNESCO 1962). Where settled communities are able to recognize, protect and "produce" beauty issues rather than individual interests, territory has a greater ability to magnetize economic investment, stimulating the new economic activities. A beautiful landscape then becomes a driving factor of economy (Greffe 2005), when the community perceives its value and activates to preserve it. In a circular dynamics, the beauty of the landscape in turn increases the feeling of belonging, the sense of community (Fusco Girard, Nijkamp 2005), and encourages maintenance processes, which result in the conviction that "it is good to" take care of the place. Putting the beauty of the landscape in the center of the transformation process has a double meaning. On the one hand, it means preserving historical beauty, while maintaining efficiency in dynamic processes that shaped the built environment over time as a complex ecosystem. On the other hand, it means reversing the degradation processes and closing the loop between resources and landscape features, enabling new relationships between place and community.

It becomes necessary to "redesign aesthetic of existence", to move beyond the void of appearances, to rethink the unique space of poiesis, its not transitory, its form, its essence, to approach art, not retaining to the past, but saying modernity opposed to conformism (Trione 1996).

\subsection{Measurable relationships of landscape}

The interactions between community and built environment can be measured by a system of indicators, which allows not only to make communicable and sharable design and selection criteria, but also to determine causal links between heritage and society, while improving the forecasting ability and choice of everyone involved. It allows us to analyze the results of already tested practices, identifying weaknesses to be improved and strengths to be proposed; thereby it facilitates the construction of new tools to support decision making regarding the implementation of UNESCO (2011) recommendations.

The set of indicators must describe the different relationships which feed the landscape system and can be so classified:

1. actions of people on built environment through intangible cultural capital;

2. relations between physical attributes of built environment;

3. influences of built environment on people;

4. internal relationships of heritage community (social capital);

5. relationships of landscape with external environment.

It is interesting to note that there is a close interaction between every single set of indicators in our framework, as every set is both effect of the previous set and cause of the next one. The process of empowerment activated is a regenerative process of development, capable of activating new circular processes, that in turn can face social and physical degradation.

The first series of indicators describes the way in which community is related to built environment through strategies and actions aimed at caring the built environment and at continuing the creative process of landscape production (Magnaghi 2010). In the existing literature, built environment indicators are mainly insufficient and must be improved (Lynch, Mosbah 2017). Indicators related to the attitude of people towards the built environment are useful in order to prove with facts their place-attachment and to make it measurable.

As pointed out by some researchers (Brown et al. 2003, Eshelman, Evans 2002), maintenance and "home personalization" reveal place attachment, whereas observed 
incivilities (vandalism, litters and graffiti, ...) predict lower place attachment. The relationship between people and place can be measured also through the attitudes to pro-environmental behaviour (Sanchez, Lafuente 2010, Dunlap et al. 2000), that are strongly linked to values and identity (Gatersleben et al. 2014). Some indicators related to actions of people on built environment have been highlighted in a study aimed at measuring sustainability progress at local level in the United States (Lynch, Mosbah 2017).

Indicators as care, maintenance, recovery and reuse of existing buildings, care and cleanliness of public space and lack of vandalism (Ipsos MORI 2015, Campos, Oliveira 2016), recycling and saving water, saving energy are effective in evaluating the relationship between people and place without resorting to a psychometric approach (Lynch, Mosbah 2017). This paper suggests how to integrate existing indicators with new ones, that better describe the way in which local community acts on the built environment. We suggest to enrich existing literature with new indicators (see Appendix A) as reuse of built heritage, production of site specific art work, integration of art in public spaces, use of public space for artistic activities, rate of local materials and technologies, rate of bioclimatic design solutions, lack of vandalism.

The second kind of indicators describes physical changes produced by the actions of people on place, understood as changes to the structure of the built environment system. This kind of indicators has been mainly studied in the field of visual indicators (Ipsos MORI 2015, Tveit, Sang 2014, Campos, Oliveira 2016), as they are able to describe how much and why a particular place attracts people and activities. Landscape preferences are basically linked to nine visual concepts: naturalness, stewardship, complexity, imageability, visual scale, historicity, coherence, disturbance, ephemera and security (Tveit, Sang 2014). Although our framework excludes some items that are contained elsewhere, indicators related to built environments already proposed in existing literature, as size and quality of public spaces, length of pedestrian paths, preservation status of old buildings, presence of green and open spaces closed to traffic, harmony in dimensional characters (lack of dimensional misalignments in heights), are useful to describe changes in the relationships with the built environment. Aiming to relate built environment to health, an early study conceived by the City Wellbeing Program in Australia (Paine, Thompson 2016) proposes a framework of indicators related to the quality and attributes of built environment, which are very useful in describing internal relationships of built environment system.

Whereas indicators which describe actions of community on built environment and its changes are quite easy to measure, as they can measured mainly through physical dimensions, it is much more difficult to measure the influence of built environment on community and the changes of its internal relations.

Although it is still unclear whether and under what conditions cultural heritage produces beneficial effects on economic development and social community, many areas of impact have been highlighted (D'Auria, Monti 2013).

Starting from research on social capital conducted by Putnam (Putnam et al. 1993, Better Together 2004) and in parallel by Matarasso (1997), it was possible to dissolve the dilemma of whether heritage is "use or ornament". But nevertheless the link between cultural heritage and sustainable development, while described in detail, is still mainly committed to a framework of indicators mostly perceptual and descriptive, based on surveys, interviews, narrative arguments, which cannot determine the causal links between heritage and social growth (Cicerchia 2015).

Earlier studies (CHCFE 2015, HLF 2015) highlight the ability of heritage (and landscape) to enhance both personal and social development. A significant contribution to the identification of social impacts of heritage comes from some studies on the impacts of art on people and communities (Brown 2006, Bollo 2013, Brown, Novak-Leonard 2007, Carnwath, Brown 2014). This field of studies pointed out that cultural participation produces personal and social impacts, not only during the cultural event or immediately afterwards, but also long after the event. In fact, the changes in our beliefs, skills and attitudes rarely are perceived during cultural participation, as they require a sedimentation time before they manifest themselves. The extended impacts, that manifest themselves through behaviors and concrete actions, need a long time (Carnwath, Brown 2014) and 
can culminate in other similar impacts. Just cumulative impacts generate significant results in terms of sense of belonging, mindedness, mental health and well-being.

Aiming at describing the influence of built environment on people, individual impacts of heritage can result in three main areas of impact: learning, skills and personal development; improved physical and mental health; cultural activity and well-being (HLF 2015), which increases the level of satisfaction with their lives. Indicators can be distinguish in three relative subcategories. The first one includes indicators as participation in lifelong learning; attending of upper school; students level of literacy and numeracy; level of ICT competencies; specialization in the high knowledge intensity. The second one includes health indicators as life expectancy and healthy life at birth; age-standardised cancer mortality rate (19-64 years old) and mortality rate for dementia and related illnesses (people aged 65 and over); life expectancy without activity limitations at 65 years of age; stress condition. The last one, related to cultural participation, includes involvement of disadvantaged people; incidence of knowledge workers on employment; social and civic participation; voluntary activities.

The systemic structure of social community makes social impacts of heritage more important than the sum of individual impacts. As it improves personal development, in turn heritage induces the improvement of interpersonal relationships. In literature, social impacts of heritage on community relate to three areas of impact: greater interaction between people, that hence the strengthening of social capital; a deeper sense of collective identity, linked to sense of place; enhanced levels of awareness and understanding between particular groups, with a positive effect on community cohesion (HLF 2015).

A significant attempt to make measurable social impacts of heritage on community has been experienced by Dzialek (2014), which, in studying the link between social capital and economic development in different regions of Poland, has brought a number of indicators derived from statistical studies, to three independent components, "formal bridging social capital", "informal bonding social capital" and "informal bridging social capital", stressing the distinction between bonding social capital and bridging social capital (Putnam 2000).

Recently two additional forms of social capital have been added: linking capital, which describes the ability to connect in a vertical direction, and it is the basis of participation around a shared project of individuals with interests and levels of responsibility also very different from each other (Szreter, Woolcock 2004) and can be considered a vertical bridge between powers and asymmetric means (Prior, Tavano Blessi 2012); bracing social capital (Rydin, Holman 2004), used to describe a combination of bridging and bonding capital, but with more attention to the combination of weak and strong bonds in networks. Bracing social capital can be a valid descriptor of hybrid processes of social innovation (Holman, Rydin 2013).

Of special interest are the studies conducted since 2010 by CNEL and ISTAT to measure "fair and sustainable wellbeing" (ISTAT 2015), which integrates indicators of economic, social and environmental measures. The initiative follows the international debate, stimulated by the Stiglitz-Sen-Fitoussi Commission and the international initiatives of the OECD, to measure the progress of societies beyond the PiL (Cicerchia 2015).

This study, that provides every year new data, proposes many useful indicators, able to describe the impact of built environment on the community and the relationships of landscape as a complex system.

The impacts of heritage on community can be expressed as changes in conditions or internal relations, encouraging dialogue between persons not belonging to the same social circle, stimulating acceptance diversity, openness, helping the understanding of different ideas. This type of phenomenon is described through indicators that measure the relatedness of the community and mainly to the presence and density of local associations of various kinds (sports, cultural or social). Other indicators describe the transformation of bridging social capital in bonding social capital and creative growth of the community through the development of cooperative and synergistic initiatives, linked by "working together", which become the glue of society and the engine of attractiveness and competitiveness of the local economy.

The last set of indicators describe the exchanges of information and people with the external environment of landscape as an open system. The possibilities to exchange 
are deeply influenced by the connections to the global network (Cohen 2014), that are described through indicators as intensity of use of internet, Wifi coverage, smartphone penetration. The ability of local system to exchange information is described by indicators as numbers of start-up, research intensity, propensity for patenting, rate of technological innovation in the production system, rate of innovation of the product / service of the national production system. As art can be considered a form of communication, the exchange of artworks and products of cultural and creative industries production can be odd as indicators of exchange with external environment too. The second kind of external relationships, that describes the exchange of people, can be measured through indicators as new residents, tourists and visitors, artists, that focus on the presence of foreign people, and on the number of exchange between local community and tourists or artists, that measure more deeply the effective possibilities of change. Last set of indicators provides a final comparison of landscape attractivity through measuring web exposure, popularity index web, prizes and awards. The whole set of indicators is listed in the Appendix A.

The proposed system of indicators, graphically represented on urban maps, leads to a multicriteria approach (Cerreta et al. 2014) for assessing the spatial diffusion of sustainable and human development (Fusco Girard, De Toro 2007, Cerreta, De Toro 2012).

\section{Art for the beauty of HUL}

\subsection{From personal wellbeing to community empowerment}

The observation of the multitude of bottom-up initiatives, through the driving force of art, is producing significant results both as recovery of places and regeneration of relationships. Understanding the process by which the individual relationship between person and art contributes to activating a system of relations with the built environment and between people can lead to outline a strategy for urban regeneration processes. Artistic experience is generally a personal emotional experience, which results in a direct relationship between the artistic input and who receives it; from personal emotional experience art enhances wellbeing, also linked at making sense and satisfacting identity needs. From the personal relationship and well-being, art develops an attitude of respect, care, antithetical to the degradation dynamics that characterize the urban spaces. So, the relationship with artwork becomes an attitude of care towards a heritage which is recognized as a common good. Furthermore, sharing the same experience and the same sense of affection, people pass from feeling extraneous in the city to becoming a member of a community (heritage community) (Council of Europe 2005b) whose members recognize the same landscape as cultural heritage. So, a social relationship between people which share the same artistic experience is produced from individual relation between human and artwork. From the regeneration of relations between community and built environment it is possible to activate new virtuous development processes, linked to symbiosis between people/place and synergies between people. The ability of individuals to develop self-identity and autonomous cultural models is reflected in the production capacity of landscape, linked more and more at its ability to offer intangible components. So, art contributes to local development, as it acts on people, influencing their behaviours and openness and stimulating their learning capacity and attitude to innovation (Sacco et al. 2015).

The reconstruction of relations between individuals, community and place, driven by art, lays the foundation of a "creative environment" (Santagata 2009), in which productive synergies and regenerative are activated. These conditions are the requirements of sustainable local development (De Rita, Bonomi 1998, Ciapetti 2010), which relies on the empowerment of local communities and on their ability to produce cultural heritage, managing the change of landscape. In Italy, the white paper of creativity (Santagata 2009) proposes a local development model based on creativity and culture as engines of growth that respects the "grammar of sustainability", as it seeks not only to pass on to future generations infrastructure and cultural resources, but also to preserve equity and defend cultural diversity (Bertacchini, Santagata 2012).

The recognition of the link between creativity, innovation and local development (UNCTAD 2008) suggests to enhance the creativity of people, which is linked to the 


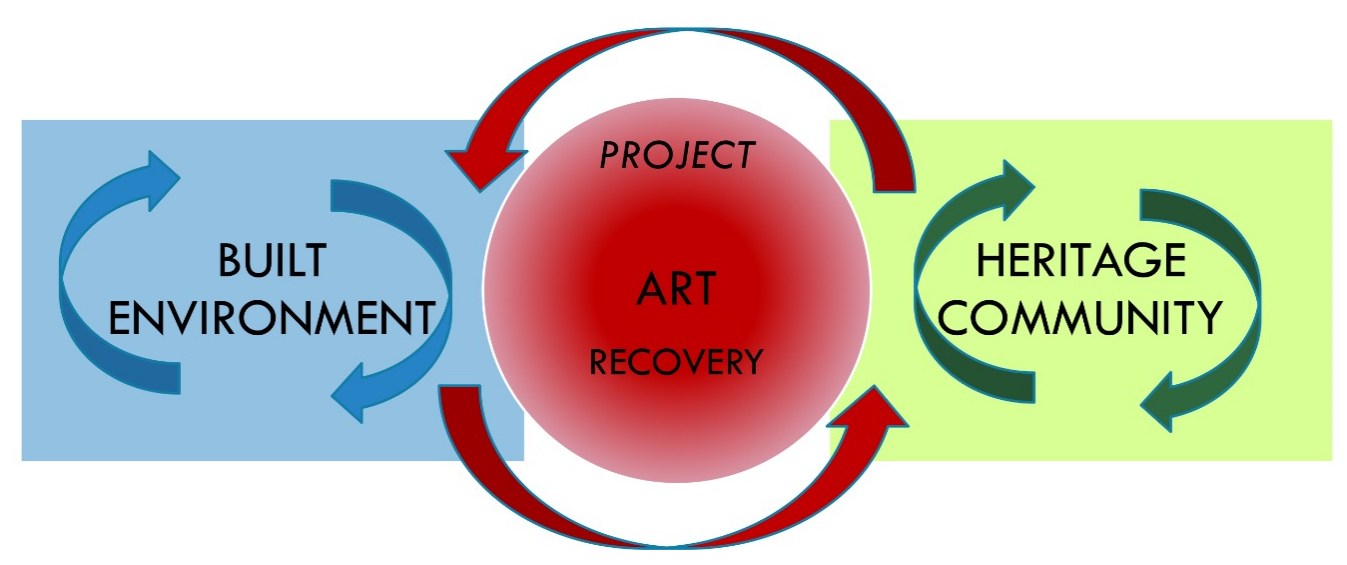

Figure 1: The contribution of art in reactiving the systemic functioning of landscape (Picture: Anna Onesti)

ability to find new and useful combinations between different elements (Poincaré 1906). Creativity of local people is fundamental in building a "creative environment", which is a milieu able to producing and disseminating projects regardless of their scope, either cultural, social, environmental and economic (Greffe 2015). Starting from the consideration that it is possible to distinguish certain activities which play a key role in producing an intrinsic motivation for creative thinking, Sacco, Segre (2009) pointed out the link between creative activities and cultural-led local development, recognizing different "rate" of creativity in human activities. Passing from supercore creativity to creativity, external aims grow up and intrinsic creativity decreases. Art, identified as super-core creativity, has a special function in the relationship between community and built environment, because it contributes to the construction of a new critical knowledge, able to recreate communities. An additional function is performed by the recovery of built heritage, creativity-core activities, which spreads and connects with the built heritage soliciting creative effects from art (see Figure 1).

The art manufacturing process, as well as the recovery of built environment, are both creative activities which, shared with local communities, stimulate individual and collective creativity. While they feed material culture, enhancing planning and designing capacity of local community and putting in relation old place and new technologies, they contribute to regenerating social capital, nurturing both bonding and social capital and building bracing capital. With the transition from personal emotions to community belonging, art contributes to producing new value creation circuits, linked to sharing capacity and cooperative, which in turn introduces new forms of wealth creation. This determines the regeneration of relationships, intended as social capital of community, physical capital of built environment and capacity to change the landscape, in a virtuous regenerative and self-sustaining cycle. As a final outcome, the art determines choral harmony, which generates a field of attractive forces in the landscape. The "beauty" of the landscape, which can be understood as a reflection of an ecology ecosystem between community and built environment, become the main indicator of this harmony. So, it's possible to argue that art contributes to the beauty of landscape not as a decoration but as structural process that guides local communities in the recovery of relationships. Through signs, forms, actions, gestures, the artist invents relationships. Every new artwork is a proposal for how to inhabit a common world (Bourriand 1998).

\subsection{A practice: the MAAM, Museum of Other and Elsewhere, in Rome}

On March 2009 a group of about 200 people, mainly immigrants, with the support of an organization for the right to housing, occupied an abandoned factory of about 20 thousand square meters in the eastern suburbs of Rome. Few months later, Giorgio De Finis, anthropologist, art curator and filmmaker, with the filmmaker Fabrizio Boni, proposed to the occupants to make a documentario, called "Space Metropoliz", showing 
the preparation of a surreal journey to the Moon, the only place available for them. The movie Space Metropoliz (released in 2014) became an opportunity to engage artists and scientists in working with Metropoliziani, teaching them about the moon and building the rocket. At the end of shooting, Metropoliz hosted many artworks, strictly related to the place, and the inhabitants of Metropoliz, feeling "protected" by art, asked to continuing the "game". With more than 500 artworks site-specific and more of 400 artists involved, today they shape Museum of Other and Elsewhere of Metropoliz, one of the most important cultural institutions of Rome (De Finis 2015). MAAM is a new kind of museum, real museum (Pietroiusti 2015) in which people live, taking care of their heritage. Flavours, colours, sounds, art works, historic industrial heritage are integrated in a strange harmony, which confuses art and life in a unique mixed city.

Passing from an "utopia of escape" (to the moon) into an "utopia of reconstruction" (Mumford 1922), MAAM demonstrates that art can be instrumental to build community values, not only interpersonal ones but also interethnic, transforming a disenfranchised group into a heritage community (Council of Europe 2005b). MAAM is recognized by the community as a common good and has established a symbiotic relation between inhabitants and place.

The process through which the art becomes driver of endogenous development can be glances by the following model, that becomes also the reading scheme of the MAAM experience:

- Art as game, Space Metropoliz. The film, presented out of competition at the Venice Film Biennial in 2014, introduces art as both a Trojan to penetrate into the occupied factory and a relational device to liberate the imagination of people and to free them from the burden of everyday life. Intended as a game which makes men free (Schiller 1793 cited in Berleant 2004), art returns to artistic dimension a context without any chance for redemption. Imagining a different world gives Metropoliziani the hope to improve their lives and to build a better future.

- Art as an utopia, a project of change. Passing from Space Metropoliz to MAAM Museum, art guides the transition from an utopia of escape to an utopia of reconstruction (Mumford 1922). Instead of telling the journey of Metropoliziani to the moon as "a happy ending", MAAM shows the physical and social recovery of Metropoliz, which is closer to architects than to artists. Integrating people needs and spacial quality, art contributes to rethink the world and contributes to regenerate social institution and urban community, starting from the recovery of public space, with places for socializing.

- Art as knowledge and communication. Art is instrumental both in learning about the moon and in exhibiting Metropoliz to Romans. As first artworks of MAAM, Gian Maria Tosatti realized a large telescope and placed it on top of the tower, with the collaboration of local inhabitants in cutting, assembling and welding the metal. In a similar way, Hogre made a big sign, with a height of $30 \mathrm{~m}$, which points the way to the moon. As a new urban landmark, these two artworks mark the landscape, referring an idea of art as an ethical sign, which binds matter and thought (Leroy-Gourhan 1964, Lukàcs 1975).

- Art as a barricade. At MAAM, art continuously produces not only cultural values, but also economic, recognized outside, which protect the community from forced eviction and the site from destruction. The demolition of the factory, which would be necessary to the realization of the building complex originally planned, would look more and more like the serious destruction of an artistic valuable collection of hundreds of works recognized by the art system.

- Art as relational system, connecting human activities. At MAAM, art has also another aim: to avoid the enclave effect and open the gates of Metropoliz to the city, sewing together two extremes of the contemporary city, the art museum, the highest place par excellence, and the slum, the lowest and degraded. The attractive power of the art collection of MAAM creates a stream of visitors, who never would have 
Table 1: actions on built environment

\begin{tabular}{ll}
\hline $\begin{array}{l}\text { Maintenance and } \\
\text { recovery activities }\end{array}$ & Diffused in the site \\
Artworks & 500 \\
Production of films & 2 \\
Exhibitions & Venere degli stracci by \\
& M. Pistoletto held in \\
& 2015 \\
& 1 (Pinacoteca \\
Art gallery & Domestica Diffusa. \\
& Diffused exhibition of \\
& artworks in houses) \\
books production & 3 (with Facoltà di \\
Workshop for & Architettura Roma Tre \\
self-construction & $2011 ;$ kids rock \\
& supported by Commons \\
& Camp and Studio \\
& Superfluo, 2015) \\
to the maintenance of artworks
\end{tabular}

come into contact with this type of community. In this way, art puts in relations Metropoliz to Roma and Tor Sapienza neighborhood, contributing to explain the housing crisis and the serious situation of tens of thousands of people deprived of basic civil rights: school, medical care and voting. Art is in the MAAM a meeting and reporting system to look at others without prejudice.

- Art as a real museum, a new landscape. It develops the idea of a "real" museum (Pietroiusti 2015), an object that exists, has a current consistency in the order of things, concerns facts and existing people, in opposition of the contemporary art museums, unreal objects, seemingly imposed. MAAM can be intended as "place of the Muses", center of knowledge, a place where human activities are connected, as it has been theorized and experimented by Michelangelo Pistoletto (2003).

\subsection{Relational indicators at MAAM}

The abandonment and degradation that characterized this site before were so strong that social capital had zero value and social dynamics were stationary. In this sense, we can suppose that the social and cultural growth of these communities had no other origin than the process of "recovery" under study.

MAAM can be considered an avant garde for its highly experimental and innovative character, far from ordinary and institutional contexts. For this feature, it can not be replicated elsewhere as it is, but is very useful in order to understanding the relationships that the recovery of public space configured by social art can activate between people, place and community and the processes of involvement of local communities.

Although it was born in an illegal context, free from international policies, MAAM is first of all an approach to local development that, starting from the recovery of public space, acts not only on both physical space but on local people too, as it transforms them in a high quality place and a heritage community strictly linked. MAAM offers a possible answer to some question proposed by United Nations with SDGs as it unconsciously relates to the urban goal, that points out the necessity to make cities more inclusive, secure, sustainable and resilient. MAAM can be considered a good practice for scientific interest because, aiming to rebuild a micro community through the recovery of public space, it tests an innovative tool that although externally-led, as it is a cultural and architectural project, since its birth continuously incorporates community in each phases of development. It is interesting to stress that MAAM came from a specific request of people lived in Metropoliz that, after experimenting the power of art in protecting them 
Table 2: Internal relationships of built environment

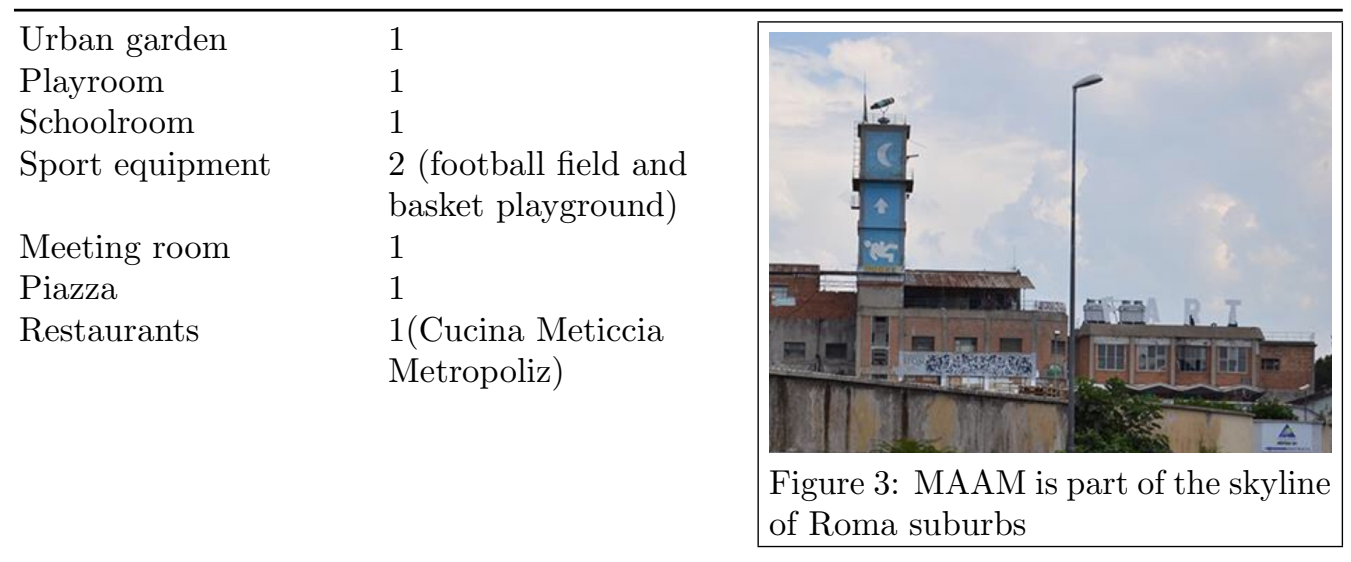

Table 3: Internal relationships of heritage community

\begin{tabular}{|c|c|c|}
\hline $\begin{array}{l}\text { Local community- } \\
\text { culture }\end{array}$ & 200 & 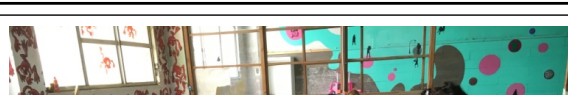 \\
\hline $\begin{array}{l}\text { Local community- } \\
\text { people }\end{array}$ & 200 & $y$ \\
\hline $\begin{array}{l}\text { Local community- } \\
\text { public }\end{array}$ & 200 & $B$ \\
\hline $\begin{array}{l}\text { Involved disadvantaged } \\
\text { people }\end{array}$ & 200 & \\
\hline Children involved & 70 & \\
\hline Afterschool programs & daily & \\
\hline Sport associations & Football team & \\
\hline Sports & $\begin{array}{l}\text { Weekly tournment of } \\
\text { football; Tournament }\end{array}$ & $\begin{array}{l}\text { Figure 4: Art workshop for children in } \\
\text { the MAAM ludoteca (playing room) }\end{array}$ \\
\hline & $\begin{array}{l}\text { "Mediterraneo } \\
\text { antirazzista" }\end{array}$ & \\
\hline Educational workshops & 1 & \\
\hline No profit organizations & 2 & \\
\hline
\end{tabular}

against forced eviction, proposed to de Finis to continue the "game of art".

Inhabitants of Metropoliz approve every artistic proposals, interact with artists (see Figure 1), sometimes providing material help in building artworks, but never replace artists. MAAM is not an experience of co-design or co-recovery, as it doesn't comes from a local community project, but from a cultural and social project based on community needs and daily shared with them (see Figure 2). MAAM is also supported by third sector organizations and by scholars and cultural associations: in its implementation it proposes a new comprehensive participatory dynamics, which clearly outlines the role and responsibilities of each actor (see Figure 3). Although developed out of the institutional framework, MAAM is an example of hybrid tools for local development through the recovery of public space.

At MAAM art, that is mainly for local people, becomes from a protective barricade a common good, inseparable from the built environment, as people increasingly link their identity to Metropoliz (i.e. they say they are Metropoliziani) and become more and more empowered in place care and management (see Figure 4). Through MAAM museum people of Metropoliz are becoming a heritage community (Council of Europe 2005b), as a social organization that establishes a system of relations and interrelations and adopt a language of its own, through which it communicates with the external environment.

Interactions of people from different countries, ethnicities, social and cultural conditions makes cultural diversity the core elements of MAAM. Although at MAAM art is for 
Table 4: Relationships between landscape and external environment

\begin{tabular}{ll}
\hline Residents & 200 \\
Tourists & Not available \\
Exchanges tourists/ & Open every Saturday \\
local community & \\
Exchanges artists/local Daily \\
community
\end{tabular}

residents, it attracts more and more visitors and it is counted on official Rome website site among main art museums.

Experimenting the proposed framework of relational indicators at MAAM is very useful in order to both understanding and checking the systemic impacts of art on people and place and to testing the application of the framework into a real context.

The first set of indicators (see Table 1), related to the actions of people on built environment, shows very interesting results, as at MAAM more than 500 artworks site specific have been produced (De Finis 2017). Also many cultural events have hosted at MAAM, and are characterized by the strictly integration between cultural activities and public space. This process is accompanied by many maintenance and recovery works and by the reuse of many abandoned space, that are mainly done by local people.

This first set of indicators suggests that art is driver on a new attitude towards built environment.

In turn, this process changes the internal relations of built environment, as it creates new available spaces and new internal paths. The second set of indicators (see Table 2) shows new collective set of spaces: urban garden, playroom, restaurant, meeting room, square and sport equipment.

The third set of indicators (see Table 3 ) reveals the impact of the process on local people (not only adults but also children and young people) through measuring their active participation to culture and their involvement in the management of Metropoliz. This process of social involvement in turn causes the growth of new collective forms of social capital that, although informal, highlights the production of both bonding and bridging capital. Whereas the first one describes the growth of strong relationships between people, and can be considered the glue of MAAM, the second one refers to weak links between different people, and can be considered the source of MAAM artistic and cultural force. Although the observation of the case study is still too limited in time in 
order to demonstrate that the MAAM communities is becoming a heritage community (Council of Europe 2005b), it is noticeable that it is going to build a creative milieu, a social science and cultural context, that is an essential precondition of sustainable development.

The last set of indicators (see Table 4) shows the relationships for MAAM and its external environment through the exchange of knowledge, people and materials. It is interesting to highlight that in the absence of sponsorships and a commercial promotion, MAAM fame was mainly achieved by speaking through the network and unconventional channels. The increasing number of visitors and cultural tourists identifies MAAM as a creative approaches for heritage-based sustainable development (D'Auria 2009). The results achieved at MAAM, expressed in terms of increased relations, synergies and attractiveness, suggest to consider it a best practices. All data refer to 2016.

\subsection{Towards an hybrid approach: creative crossovers and "living lab"}

The experience of the MAAM can be interpreted as a cultural project, an experiment of social art, which proposes a new dynamic and participatory approach, where the role and responsibilities of everybody are quite clearly outlined. Intended as an example of a cultural project, MAAM paves the way to a public space design aimed at producing cultural crossovers, as systematic methodologically predictable social effects. Cultural crossovers are the effects intentionally produced by the hybridization of art and culture with the most varied sectors, opposite to alternative spillovers, accidental and episodic effects of cultural policy (Sacco, Sciacchitano 2015).

MAAM suggests a process of embeddedness that we propose to implement in different and more ordinary context. In order to make the experience of MAAM replicable and transferable elsewhere, after decoding the process of empowerment of communities through artistic experience, it is necessary to test its "model" in a laboratory context through field testing. Laboratory experimentation allows us to identify cause/effect relationships and to produce empirical evidence about the role of art as a driver of human development.

Live experimentation of the proposed approach requires operational hybrid tools able to meet bottom-up approach of participatory processes with top-down scientific approach and to bring experimentation into a systematic and structured framework of innovation.

Cities are opposite of scientific laboratories that are distinctly and purposefully created to be separate from the lived world in order to manipulating variables and testing hypotheses. Through laboratorization it is possible to set boundaries where controlled experiments can take place and be recorded, in order to transform events/experiments into facts/knowledge. The real world can function as a laboratory, since it adhere to life 'as it is really lived' (Evans, Karvonen 2014). In order to produce laboratory knowledge and make communicable and sharable causal links, it's necessary both to set material, institutional and conceptual boundaries to the testing field and, through measurable indicators, to provide a richness of data that allows statistical patterns to emerge.

An useful tool for hybrid approaches are Living Labs, that were developed in the 90's within MIT, Massachusetts Institute of Technology, with the aim of making knowledge, experiences and daily needs of people the starting point of innovation. Defined by the European network ENoLL (www.www.openlivinglabs.eu) as "user-centred, open innovation ecosystems based on a systematic user co-creation approach integrating research and innovation processes in real life communities and settings", Living Lab is both an approach and an arena (Schliwa 2013) and is characterized by three main features:

1. being confined in a geographically or institutionally bounded space;

2. making social and/or material alterations aimed to conducting intentional experiments;

3. incorporating iterative learning into the process.

Living labs have been exploited as an effective tool in the transitional phases from spontaneous collaboration practices to the empowerment of local communities for local development as they represent a model of territorial innovation based on social economy and community governance (Concilio 2013). 
Living lab seems to be a very effective tool that supports the recovery of public space, making it a social innovation and culture-driven tool. As testing arena, Living lab can coincide with public space, that in turn through live experimentation becomes place of social innovation. As place where social processes mainly happen and have a social balancing attitude (Caterina 2013), public spaces become the testing arena for an approach to recovery that actively involves and embeds the whole community.

\section{Case study: HUL of Torre Annunziata}

The paper focuses on the town of Torre Annunziata, in the Vesuvius area, a case study particularly relevant because it documents a productive landscape (Tempesta 2009), characterized by the symbiosis of a local community dedicated mainly to the production of pasta for food use and a built environment configured for its production (Viola et al. 2014).

Since the nineteenth century, a lot of pasta factories (102 pasta factories; 1.678 employees) prospered thanks to climate attributes (continuous ventilation and good sun exposure), infrastructure (a canal from Sarno river and an industriousness seaport) and the special knowledge of the pasta drying process, imported by a community from Amalfi (Abenante 2011). The urban landscape changed according to the production process; ground floors and basements of residential buildings housed productive uses; a strong link characterized the continuity of public spaces and spatial elements, open up on the street in order to airing and drying pasta and moving raw materials and finished products (Diano 2015). The built environment was configured as a bioclimatic system, which used natural ventilation and rainwater harvesting to facilitate the manufacturing and drying process of pasta production (Napolitano 2015). Airflows, cooled and purified in the transition from green areas, were conveyed into the buildings by means of special architectural concept (Pinto, Viola 2015).

The "quartiere murattiano", Murat district (see Figure 6), developed along two main streets, Via Mazzini and via Oplonti, and bordered by Via Murat and Corso Umberto, hosted the largest concentration of pasta factories, with over one hundred pasta factories in the early twentieth century (Pinto, Viola 2015). Today there is a single pasta factory, the only heir of the local tradition, which preserves a collective memory. The buildings for the production of pasta, arranged along a green area, which favored the ventilation of buildings, have been transformed by various actions that together have altered the character of the area, as well as the green band has been parceled and occupied by a series of poor quality buildings.

The study of Murat district is especially important for knowing dynamics and relationships of the urban landscape system.

The beauty of Torre Annunziata, main indicator of the harmony between communities and built environment, declined with the collapse of pasta production, caused by the interaction of different external pressures. The decommissioning of pasta factories broke the relations between communities and built environment: local community is less and less able to change the built environment and, in turn, built environment produces less and less relational impacts on the community (see Figure 7).

\subsection{Relational indicators in Torre Annunziata}

In order to understand the systemic functioning of Torre Annunziata landscape, it is useful to measuring relational indicators through the proposed framework. Using the data provided by official sources, integrated with some data derived from on-site analysis, it is possible to have a rather complete picture of the situation (see Appendix B).

The first area of indicators, describing the actions of people on built environment, shows a very critical picture: many are the buildings in mediocre or poor conditions and the index of deterioration is significant, although there is a fairly consistent use of historic buildings.

Place attachment of local community is hard to find: streets and public space are very dirty and there are no public art installations or cultural event, except for the religious 


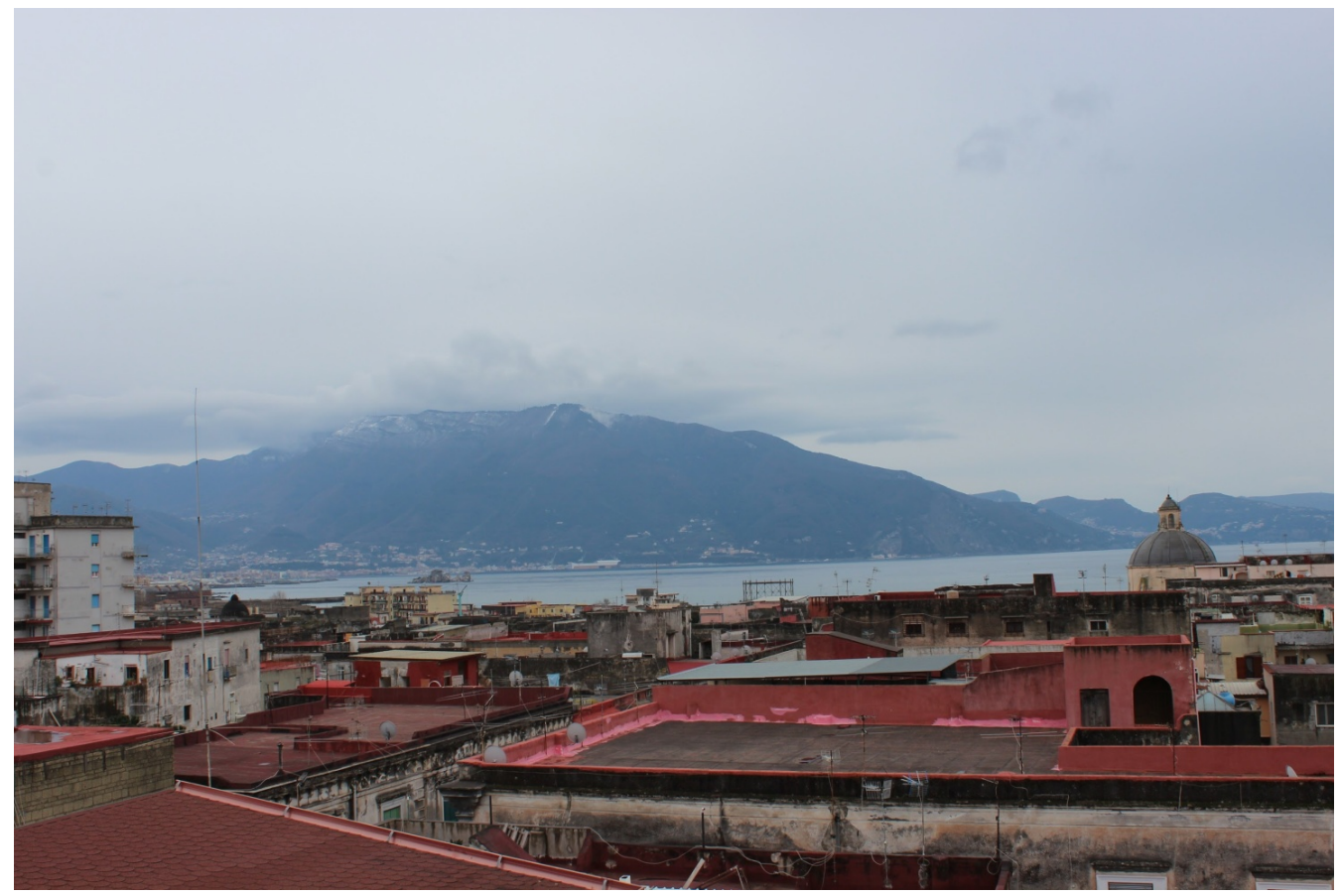

Figure 6: View from buildings roofs in Murat district with Sorrento and its coast in the background

feast Madonna della Neve (Our Lady of Snow), whose procession goes through the center of the town.

The effects of this behaviour on built environment internal relations is obvious, as the second area of indicators shows. In Torre Annunziata there are no public space available for local community and the public green space in the town is very low; incidental contacts between people are blocked more than favored along the streets, that serve only as a park and transit site for cars. All this happens despite the area being subject to legal protection constraints due to the presence of cultural heritage and historic landscape as Oplonti site. These indicators highlight the quality of built environment as a potentiality to improve. Other potentialities are in the bioclimatic functioning of many buildings (ventilation, water recycling system) that, although not in use, can be recovered in order to minimize the consumption of resources.

The influence of built environment on people is very weak: participation in lifelong learning, rate of adults with high school diploma or degree, rate of young people with university education and specialization in the high knowledge intensity are low in Torre Annunziata and lower in Murat district. In turn, the incidence of people not engaged in education, employment or training is quite high. Although they refer to the whole metropolitan area, health indicators as life expectancy at birth and age-standardized cancer and dementia and related illness mortality rate show a low level of well-being. Social participation of people is quite low, as participation rate in election indicators highlight. Volunteers rate and non-profit employees rate are similarly very small, showing low participation of the population in the community social life.

All this results in the scarcity of relationships of heritage community, with few social cooperatives and non-profit organizations.

At the end of our analysis, the last set of indicators, that describes the relationships between landscape and external environment, highlights the whole system criticality. The exchanges of information are very poor as indicators as propensity for patenting, patent impact in innovation sectors reveal. The exportation of art and cultural and creative industries production, that can be considered a form of exchange of information, is virtually zero. The only significant exportation of high quality goods is related to the pasta produced by the only still active pasta factory, that exports its products in USA, 


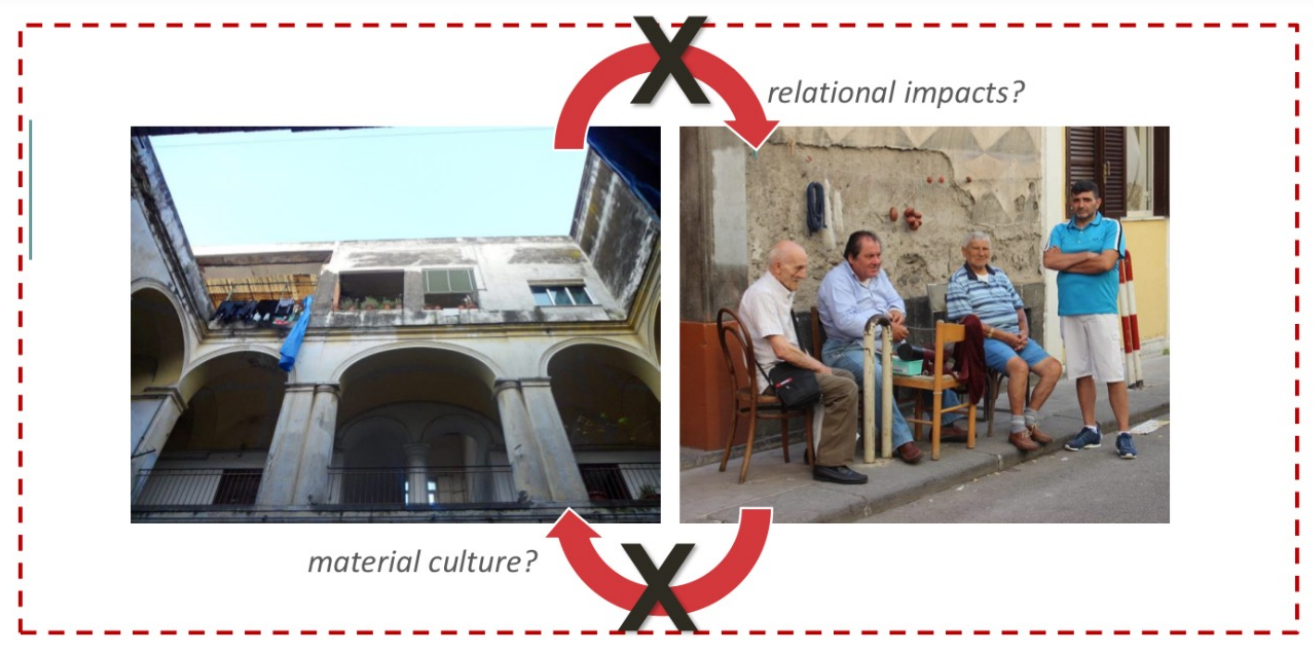

Figure 7: Buit environment and local community decay in Torre Annunziata

\section{UK, France, Spain, Germany, Austria, Greece, Emirates, Japan, Australia.}

The exchanges of people, both residents and visitors, are very poor too: demographic variation shows shows a loss of 4490 units from 2001 to 2011 and tourist flow is almost nil, with the exception of visitors to Oplonti archaeological site, which only stay for the time of the visit. Last set of indicators, that provides a final comparison of landscape attractivity by travel reviews on web (TripAdvisor) definitively highlights a very low attractivity of Torre Annunziata and mostly of Murat district.

The whole set of indicators related to Torre Annunziata is listed in Appendix B.

\subsection{What of MAAM is replicable in Torre Annunziata?}

The recovery of built heritage, while necessary, is not enough to improve the quality of landscape and activate a new development, unless it is not accompanied by the reactivation of local communities and the recovery of their ability to relate to the built environment. This awareness calls for a reflection on cultural and social dynamics capable of contributing to the process of empowerment of local communities.

In order to reactivating the systemic functioning of Torre Annunziata landscape and improving its "beauty", it is necessary to recovery the creativity of its local community, which leads to regenerating the system of relations between people, communities and environment. In order to activating this process, the study suggests to use art as a driver.

We can argue that, first of all, it is replicable the founding idea of MAAM that art, even though cannot bring people on the moon, it can help people to build the moon here on Earth (De Finis 2015), contributing to get people to think differently and to make public space available for the whole community.

It is also replicable the idea that art can be the driver for building a creative milieu, which is the requirement for local development. It's useful to underline that art cannot be considered the characteristic vocation of a place, but the structural element which drives the development and characterizes every place. MAAM is also replicable as a cultural project, in which the physical recovery of public space, configured by art, is instrumentally used to produce social and cultural crossovers: the recovery of public space, as place of relationships, is able to produce social crossovers, depending by both the architectural/artistic design choices and the process of empowerment of local community. MAAM is not a project of self-recovery, but it is a project strongly focused on the need of marginalized communities who occupy the building, which is shared each day.

Though it is impossible to replicate the experience of MAAM, it is possible to reply the process of empowerment, through which art involves local community: it starts from suggesting art as game, an embedding process by which local community can be involved in an utopia, project of the change. This model is based on art as knowledge disposal 
and produces a barricade, a system of new values able to protect people and place from external influences, and a relational system, which supports the exchange of information between people. At the end, art makes a new landscape, a real museum, intended as "place of Muses", a place of reproduction of cultural and social values. In its practical implementation, this approach leads to test new forms of landscape management, based on the recognition of public space as a commons.

\subsection{Attributes and value of art in three different scenarios}

For the development of Torre Annunziata, three different scenarios have been proposed in the PRIN research project (Fusco Girard et al. 2016) developed from Department of Architecture of University of Napoli Federico II: productive networks, touristic hub and centre of sustainable consumption and production. A way to compare them is comparing the meaning of art in each one (see Figure 8).

The first scenario, productive network, sees Torre Annunziata as a place of typical production, strictly linked to tourism. This scenario can include the production of artworks and crafts. The production of art is limited at tourists as customers and art is intended as a private good to take away and is supported by traditional economy, market driven. Art is here instrumental in adding economic values and could produce social spillovers linked to the involvement of local artisans. The second scenario, touristic hub, sees Torre Annunziata as a resort area with accommodation and playground facilities instrumental to increasing residence time of tourists. This scenario can include art both as big event and temporary occurrence and as decoration of touristic places. Art is only for tourists and is intended as a foreign art, imported in order to satisfy the market demand. Art is supported by traditional economy and is a potential source of gentrification. It is instrumental in adding economic values and nurturing local attraction capacity, but it can produce social spillovers, linked to the interaction between residents and tourists, nurturing the sense of identity.

Although the proximity to heritage site and the beauty of Torre Annunziata landscape suggest to focus on cultural heritage as a source of local economy, tourism is not necessary the right way to pursue it, whereas it is one of the fastest-growing economic sectors in the world. Putting tourism at the centre of local development can produce many distortions, as pointed out by an early study (Romão, Nijkamp 2017, WTO 2017). With considering tourism central in local development processes, the recovery of public space must focus mainly on the needs of tourists and only afterwards on the ones of local community. This approach brings to exploit cultural heritage as an economic asset to be exploited in order to meet touristic demand, with a customer oriented strategy mainly based on a oleographic vision that progressively silks its authenticity, cultural vitality and ability to innovate (Sacco et al. 2015). Landscape and cultural heritage are lever for sustainable development, in both economic and environmental, social and cultural terms (Fairclough et al. 2014) as they are vital resources for the citizens (European Commission 2015).

Furthermore, the process of high and quick development of tourism potentially contributes to the reduction of the importance of other economic sectors, including agriculture and manufacturing. In turn, it produces a negative correlation between the rate of workforce employed in tourism and both tourism competitiveness, levels of productivity, resilience (facing economic crisis in 2007), education of population, investments in R\&D and attitude to innovation.

But if tourism is programmed and oriented, it can contribute to local sustainable development as it produce a myriad of interactions between insiders, which daily live the place, and outsiders, which see landscape with different eyes. As it contributes to rediscovering the sense of belonging and in turn to re-activating the bond between people and place, this kind of tourism is able to produce circular relationships with local community. The development of tourism related activities must be shared with local community and followed by the development of other economic sectors, able to integrate knowledge, innovation, qualified human resources and value added.

The third scenario, centre of sustainable consumption and production, sees Torre Annunziata as a node in a network of places dedicated to the production and consumption of local goods, as food and crafts. This scenario does not contrast with tourism, but rather 


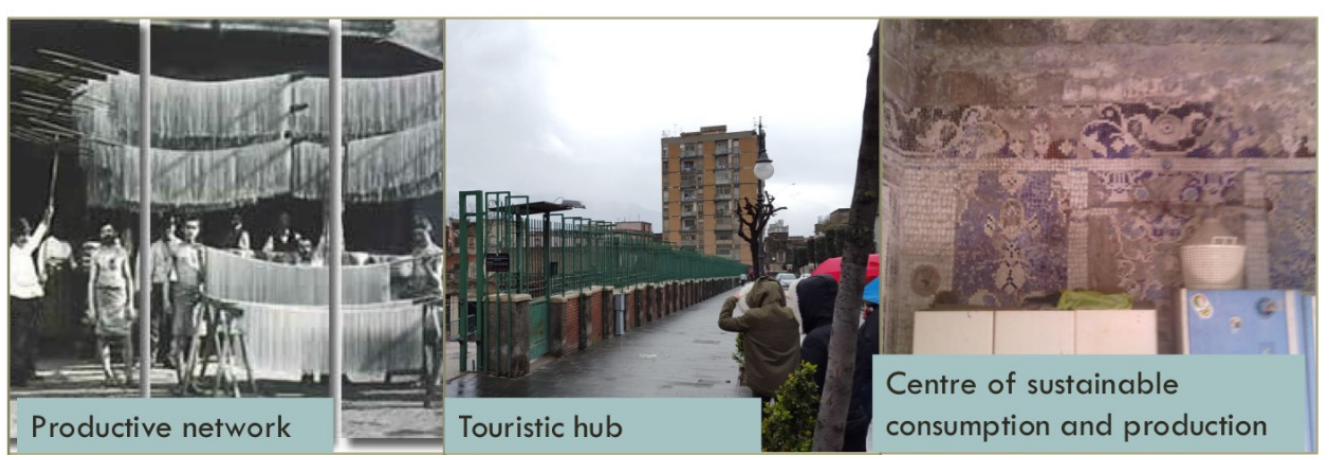

Figure 8: The contribution of art in the proposed scenarios of development

it contributes to develop integrated economic activity and to improve the relationships of tourists and local people. This scenario relates traditional pasta production to the proximity of archeological sites of Villa di Oplonti and Pompeii ruins. Art is intended as daily, permanent opera, produced locally and site-specific. It is mainly for residents though it is a source of attraction for tourists. This kind of art, called social art, is supported by new types of economy as collaborative and sharing economy and is an aid for facing new urban challenges, which are evident in Torre Annunziata. In the third scenario, art is instrumental in adding economic/cultural values and in engaging people, sharing knowledge, connecting people, designing urban recovery, finding the strength for change. It produces social crossovers as it causes the regeneration of relations and inter-relations between people and built environment. The third scenario seems to be the best solution in order to improve the quality of landscape and activate a new development, driven by the reactivation of local communities and the recovery of their ability to relate to natural and built environment.

\subsection{Towards a new beauty: art, recovery, public space}

In order to implement the chosen scenario, a priority is "regenerating the beauty" of public space, recognized as a space of social capital par excellence (Bullen, Onyx 1998, Prior, Tavano Blessi 2012) in which to activate a new urban metabolism, based on the circularization processes and linked to the symbiotic / synergy concepts (Fusco Girard 2013). This results in actions directed towards the system of urban open spaces and the system of the semi-public spaces, where the exchanges of information, culture, goods, linked to the production and commercialization of pasta take place. The recovery of the public space proposed focuses both on streets, little squares, degraded areas, and entrance hall, courtyards, terraces and, in particular, the green area located between Via Oplonti and Via Mazzini, which today are partly saturated by superfetations and dilapidated buildings. The regeneration of bioclimatic attributes of buildings and urban fabrics, which were once functional to pasta production, can produce added values for both low energy manufacturing and residential and urban comfort. In this sense, the intervention of recovery, which is characterized by the search for a balance between conservation and innovation, can promote a renewed and fruitful dialogue between innovative approaches and local building culture and to activate new synergies and impulses with effects on local economy (Caterina et al. 2015).

In the process of recovering this area, art assumes, as described, a structural function and researches the physical and symbolic integration with architecture. In the past the relationship between art and architecture, called syncretism, was common; in Italy it's still mandatory to allocate a percentage of the budget of public buildings to "make them beauty" through art works (law nr. 717/1945). To this end, the project of recovery must identify spatial and technical elements to make the sublayer and the background of artworks, symbiotically integrated with architecture. The project provides the installation of sculptures and spatial installations along the open area between buildings which, cleared from accretions and shanties, becomes a path in the green, to be used not only as a place 
of recreation but also as a slow mobility path. Artworks are also integrated in the street space, configuring the external walls of buildings, especially those with no architectural value, in order to give new meanings to public space and to reconcile differences between new and historical buildings. Although it is mainly focused on the public space, the proposed intervention is completed with the re-use of abandoned buildings by providing, in addition to new production activities, residences and workshops for artists, spread in the urban fabric. The reuse is accompanied by new management mode, providing that, in exchange for their hospitality, the artists are committed to produce and leave some works, whose residents become custodians.

\section{Conclusions}

The recovery of public space pursues the creativity of local community as a preparatory action to local development and deduces from local community and its sedimented culture the enablers of development.

The recovery process proposed for Torre Annunziata suggests a hybrid approach, in which the "emotional" and community based bottom-up approach with the "rational" and scientific top-down approach are integrated.

In order to operationalise the proposed approach in Torre Annunziata, the paper proposes to use living lab as an hybrid tool able to both experiment in a real field the thesis based on art as driver of development and to really activate new development processes with the empowerment of local communities.

Living Lab is an instrument able to act as an interface between the project and the community in different stages of the process.

Living Lab, implemented in the described area of Torre Annunziata as a real environment, becomes both space of interchange between local knowledge and expert knowledge, way to evaluating relational impacts of the project, place of interaction between institutional actors and new forms of management of common space.

In order to operationalizing the role of art as driver of development, Living Lab assumes the meaning of laboratory of civil aesthetic (Fusco Girard 2012), as a place where to put together artists, designers, citizens, enterprises and associations of the third sector and to produce not only aesthetic values but also social values. The integration between art and built environment, which in the past has always characterized public places, becomes the driver of implementing new forms of communication between culture and communities and regenerating both the material culture, and social capital. Living Lab can be an operational tool for transforming public space into a creative and regenerative environment. In this way, the recovery of public space suggests an alternative/supplementary way to produce wealth and proposes a new idea of economics, as next and cooperative economy, whose core is to participate and to cooperate. It contributes to rebuild a micro-community (or networks of micro-communities), in which economy not only creates but redistributes wealth.

In conclusion, configured by art as driver of development and shared with the local community, the recovery of public space can be proposed as a tool to implement HUL approach, as proposed by UNESCO, and to make cities inclusive, safe, resilient and sustainable. At the same time, the identification of the Living Lab as an auxiliary tool in the implementation of this approach closes the loop with respect to the demand of new operational tools, promoted by UNESCO Recommendations. The approach proposed is also in line with the indications of European Council with regard to participatory governance of cultural heritage (2014/C 463/01) and is consistent with the European Council's conclusion on cultural and creative exchanges to stimulate innovation, economic sustainability and social inclusion $(2015 / \mathrm{C} 172 / 04)$. In addition, it tracks an operational approach to promote intercultural dialogue and keep the community together through culture in shared public spaces (www.voiceofculture.eu), recognizing that art must be destined to all and not reduced to additional activities for small groups of users. 


\section{References}

Abenante A (2011) Maccaronari. Ires Campania, Napoli

Berleant A (2004) The aesthetics of art and nature. In: Berleant A, Carlson A (eds), The Aesthetics of Natural Environments. Broadview, Peterborough, Ont

Bertacchini E, Santagata W (2012) Atmosfera creativa. Un modello di sviluppo sostenibile per il Piemonte fondato su cultura e creatività. Il Mulino, Bologna

Better Together (2004) Bettertogether: The arts and social capital. Saguaro seminar on civic engagement in America, John F. Kennedy School of Government, Harvard University, Cambridge, MA http://www.bettertogether.org/

Bollo A (2013) The learning museum report 3: Measuring museum impacts. http://online.ibc.regione.emilia-romagna.it/I/libri/pdf/LEM3rd-report-measuringmuseum-impacts.pdf

Bonesio L (2012) La questione epistemiologica e il linguaggio. Territorio, luogo, paesaggio. Firenze University Press, Firenze

Bouchenaki M (2003) The interdependency of the tangible and intangible cultural heritage. 14th ICOMOS General Assembly and International Symposium: 'Place, memory, meaning: preserving intangible values in monuments and sites', Victoria Falls, Zimbabwe. http://openarchive.icomos.org

Bourriand N (1998) Esthétique relationnelle. Les presses du réel, Dijon

Brown AS (2006) An architecture of value. GIA Reader 17[1]: 18-25

Brown AS, Novak-Leonard J (2007) Assessing the intrinsic impacts of a live performance. Dance Center, Columbia College, Chicago

Brown B, Perkins DD (2001) Neighborhood revitalization \& disorder: An intervention evaluation. Final Project Report, National Institute of Justice, Washington, DC, https://www.ncjrs.gov/pdffiles1/nij/grants/196669.pdf

Brown B, Perkins DD, Brown G (2003) Place attachment in a revitalizing neighborhood: Individual and block levels of analysis. Journal of environmental psychology 23[3]: 259-271. CrossRef.

Bullen P, Onyx J (1998) Measuring social capital in five communities in nsw: A practitioner's guide. Management alternatives pty limited

Campos A, Oliveira RC (2016) Cluster analysis applied to the evaluation of urban landscape quality. WIT Transactions on Ecology and the Environment 204: 93-103

Carnwath JD, Brown A (2014) Understanding the value and impacts of cultural experiences. Arts council England, London

Caterina G (2012) Prefazione. In: Viola S (ed), Nuove sfide per le città antiche. Liguori Editore, Napoli

Caterina G (2013) Conservazione, manutenzione e gestione degli spazi pubblici e dei beni architettonici. In: Castagneto F, Fiore V (eds), Recupero Valorizzazione Manutenzione nei Centri Storici. Un tavolo di confronto interdisciplinare. Lettera 22, Siracusa, 14-17

Caterina G, Bianchi A, Pinto MR, Viola S, Diano D, Napolitano T, Biancamano PF, Onesti A (2015) A participatory approach for built heritage preservation. Case study: the municipality of Sassano, Italy. In: Amoeda R, Lira S, Pinheiro C (eds), Proceedings of the 2nd International Conference on Preservation, Maintenance and Rehabilitation of Historical Buildings and Structures. Porto, Portugal, 463-470 
Cerreta M, De Toro P (2012) Urbanization suitability maps: A dynamic spatial decision support system for sustainable land use. Earth System Dynamics 3[2]: 157-171. CrossRef.

Cerreta M, De Toro P, Fusco Girard L (2014) Integrated assessment for sustainable choices. Scienze Regionali 13[1]: 111-142. CrossRef.

CHCFE (2015) Cultural heritage counts for Europe. CHCFE Consortium, http://www.encatc.org/culturalheritagecountsforeurope

Ciapetti L (2010) Lo sviluppo locale. Il Mulino, Bologna

Cicerchia A (2015) Why we should measure. what we should measure. In: Cicerchia A (ed), Economia della Cultura. Rivista dell'Associazione per l'Economia della Cultura, $11-22$

Ciribini G (1979) Introduzione alla tecnologia del design. Franco Angeli Editore, Milano

Cohen B (2014) Smart city index master indicators survey. Smart cities council, http://smartcitiescouncil.com/resources/smart-city-index-master-indicators-survey

Concilio G (2013) Innovazione territoriale e living lab. Esperienze e visioni, Cilento Labscape, Working Paper, Napoli

Council of Europe (2005a) Explanatory report to the council of Europe framework convention on the value of cultural heritage for society. Council of Europe treaty series, no. 199, https://rm.coe.int/16800d3814

Council of Europe (2005b) Framework convention on the value of cultural heritage for society (Faro convention). https://www.coe.int/en/web/conventions/full-list//conventions/treaty/199

Cuccia T, Santagata W (2003) Adhesion - exit: incentivi e diritti di proprietà collettivi nei distretti culturali, in Diritti, Regole, Mercato. Economia pubblica ed analisi economica del diritto. XV Conferenza SIEP, Pavia

D'Auria A (2009) Urban cultural tourism: Creative approaches for heritage-based sustainable development. International Journal of Sustainable Development 12: 275-289. CrossRef.

D'Auria A, Monti B (2013) The guardianship of the landscapes between identification and assessment: Ischia and its lost identity. In: Rezekne Higher Education Institut (ed), Society, integration, education: utopias and dystopias in landscape and cultural mosaic: visions values vulnerability, Volume IV. Proceedings of the International Scientific Conference on Society, Integration, and Education Location, Udine, Italy, 165-176

D'Auria A, Pugliese S (2013) The governance of UNESCO cultural landscapes between universal values and local identity: the case of Campania. In: Rezekne Higher Education Institut (ed), Society, integration, education: utopias and dystopias in landscape and cultural mosaic: visions values vulnerability, Volume V. Proceedings of the International Scientific Conference on Society, Integration, and Education Location, Udine, Italy, $189-200$

De Finis G (2015) Forza tutt*. La barricata dell'arte. Bordeaux edizioni, Roma

De Finis G (2017) Maam. Museo dell'Altro e dell'Altrove di Metropoliz'città meticcia. Bordeaux edizioni, Roma

De Rita G, Bonomi A (1998) Manifesto per lo sviluppo locale. Bollati Boringhieri, Torino

Diano D (2015) Le pressioni perturbative del sistema insediativo di torre annunziata (NA). BDC - Bollettino Del Centro Calza Bini 15[1]: 3960. CrossRef. 
Dunlap RE, van Liere KD, Mertig AG, Jones RE (2000) New trends in measuring environmental attitudes: Measuring endorsement of the new ecological paradigm: a revisited NEP scale. Journal of Social Issues 56: 425-442. CrossRef.

Dzialek J (2014) Is social capital useful for explaining economic development in Polish regions? 962[2]: 177-193. CrossRef.

Eco U (2005) Storia della bellezza. Bompiani, Milano

Eshelman PE, Evans GW (2002) Home again: Environmental predictors of place attachment and self-esteem for new retirement community residents. Journal of Interior Design 28[1]: 1-9. CrossRef.

European Commission (2015) Getting cultural heritage to work for Europe. Report of the Horizon 2020 expert group on cultural heritage, Directorate General for Research and Innovation, http://bookshop.europa.eu/en/getting-cultural-heritage-to-work-foreurope-pbKI0115128/

Evans J, Karvonen A (2014) 'Give me a laboratory and I will lower your carbon footprint!' - urban laboratories and the governance of low-carbon futures. International Journal of Urban and Regional Research 38: 413-430. CrossRef.

Fairclough G, Dragićević-Šešić M, Rogač-Mijatović L, Auclair E, Soini K (2014) The Faro convention, a new paradigm for socially - and culturally - sustainable heritage action? Culture 8: 9-19

Fondazione Pistoletto (2003) Geographies of change. A project by Cittadellarte-Fondazione Pistoletto 2003-2017, http://www.geographiesofchange.net/

Fontana C (2012) Re-tracing the systemic approach in architecture, and developing working tools. Methods, Models, Simulations and Approaches Towards a General Theory of Change. Proceedings of the Fifth National Conference of the Italian Systems Society, Marche Polytechnic University, Italy

Fusco Girard L (1989) Qualità e quantità nello sviluppo urbano. i riflessi sul problema della valutazione. In: Fusco Girard L (ed), Conservazione e sviluppo: la valutazione nella pianificazione fisica. Franco Angeli, Milano

Fusco Girard L (2012) Creativity and the human sustainable city: Principles and approaches for nurturing city resilience. In: Fusco Girard L, Baycan T (eds), Sustainable City and Creativity. Promoting Creative Urban Initiatives. Ashgate, 55-96

Fusco Girard L (2013) Toward a smart sustainable development of port cities/areas: the role of the 'historic urban landscape' approach. Sustainability 5[10]: 4329-4348. CrossRef.

Fusco Girard L (2014) Editorial. BDC - Bollettino Del Centro Calza Bini 14[2]: 243-249. CrossRef.

Fusco Girard L, Cerreta M, De Toro P, Pinto MR, Viola S (2016) The PRIN research project. the cultural/historic urban landscape: A resource for urban regeneration and local development. Presentation at "The Science of the City", Advanced Brainstorming Carrefour, Napoli

Fusco Girard L, De Toro P (2007) Integrated spatial assessment: A multicriteria approach to sustainable development of cultural and environmental heritage in San Marco dei Cavoti, Italy. Central European Journal of Operations Research 15[3]: 281-299. CrossRef.

Fusco Girard L, Nijkamp P (2005) Energia, bellezza, partecipazione: la sfida della sostenibilità. Franco Angeli 
Fusco Girard L, Torrieri F (2009) Cultural tourism and strategic evaluations: Towards integrated approaches. In: Fusco Girard L, Nijkamp P (eds), Cultural Tourism and Sustainable Local Development. Ashgate, London

Gatersleben B, Murtagh N, Abrahamse W (2014) Values, identity and pro-environmental behaviour. Contemporary Social Science 9[4]: 374-392. CrossRef.

Givone S (2012) L'origine della creazione artistica. http://www.arte.rai.it/articoli/givonelorigine-dellispirazione-artistica-3-di-5/22627/default.aspx

Greffe G (2015) Culture and creativity. In: Kakiuchi E, Greffe X (eds), Culture, Creativity and Cities. SUIYO-SHA. Available at https://www.researchgate.net/publication/301603142_Culture_Creativity_and_City

Greffe X (2005) Culture and local development. OECD, Paris

HLF - Heritage Lottery Fund (2015) Values and benefits of heritage: A research review. Heritage lottery fund, https://www.hlf.org.uk/values-and-benefits-heritage

Holman N, Rydin Y (2013) What can social capital tell us about planning under localism? Local Government Studies 39[1]: 71-88. CrossRef.

Ipsos MORI (2015) Beauty and social prosperity survey 2015. Respublica London, https://www.ipsos.com/sites/default/files/migrations/en-uk/files/Assets/Docs/Polls/ipsos-mori-respublica-topline.pdf

ISTAT (2015) Equitable and sustainable well-being. Project to measure equitable and sustainable well-being 2013-2015, http://www.misuredelbenessere.it/

Leroy-Gourhan A (1964) Le geste et la parole. Albin Michel, Paris

Lukàcs G (1975) Cultura e rivoluzione. Saggi 1919-1921. Newton Compton Editori, Roma

Lynch AJ, Mosbah SM (2017) Improving local measures of sustainability: A study of built-environment indicators in the United States. Cities 60: 301-313. CrossRef.

Magnaghi A (2010) Progetto locale. Verso la coscienza di luogo. Bollati Boringhieri, Torino

Magnaghi A (2012) Le ragioni di una sfida. In: Magnaghi A (ed), Il territorio bene comune. Firenze University Press, Firenze, Italy, 11-30

Matarasso F (1997) Use or ornament? The social impact of participation in the arts, comedia, stroud. http://www.culturenet.cz/res/data/004/000571.pdf

Mumford L (1922) Storia dell'utopia (translated and reprinted 2008 ed.). Donzelli editore, Roma

Napolitano T (2015) Sistema edilizio e risorsa idrica. il caso studio di torre annunziata (na). BDC-Bollettino Del Centro Calza Bini 15[1]: 61-70. CrossRef.

Nijkamp P, Kourtit K (2012) The 'New Urban Europe': Global challenges and local responses in the urban century. European Planning Studies 21[3]: 291-315. CrossRef.

Paine G, Thompson S (2016) Healthy built environment indicators. City Wellbeing Program, CFRC, UNSW, Australia

Pietroiusti C (2015) Possibili caratteristiche di un museo "reale". In: de Finis G, Benincasa F, Facchi A (eds), Exploit. Come rovesciare il mondo ad arte. Bordeaux edizioni, Roma, 737-742

Pinto MR, Viola S (2015) Identità sedimentate e nuova prosperità per il paesaggio urbano produttivo. BDC - Bollettino Del Centro Calza Bini 15[1]: 71-91. CrossRef.

Pistoletto M (2003) Il terzo paradiso. 2003-2017, http://terzoparadiso.org/ 
Poincaré JH (1906) Scienza e metodo (translated and republished 1997 ed.). Einaudi

Prior J, Tavano Blessi G (2012) Social capital, local communities and culture-led urban regeneration processes: The Sydney Olympic Park experience. Cosmopolitan Civil Societies Journal 4[3]: 78-96. CrossRef.

Putnam RD (2000) Bowling Alone: The Collapse and Revival of American Community. Simon and Schuster, New York

Putnam RD, Leonardi R, Nanetti R (1993) Making democracy work: civic traditions in modern Italy. Princeton University Press, Princeton

Rodotà S (2012) Il valore dei beni comuni. La repubblica, 5 gennaio 2012

Romão J, Nijkamp P (2017) Spatial-economic impacts of tourism on regional development: challenges for Europe (no. 2017_01). Working paper, University of Evora, CEFAGE-UE (Portugal) http://www.cefage.uevora.pt/en/content/download/6410/76704/version/1/file/2017_01.pdf

Rydin Y, Holman N (2004) Re-evaluating the contribution of social capital in achieving sustainable development. Local Environment 9[2]: 117-133. CrossRef.

Sacco PL, Ferilli G, Tavano Blessi G (2015) Cultura e sviluppo locale: verso il Distretto culturale evoluto. Il Mulino, Bologna

Sacco PL, Sciacchitano E (2015) Incroci creativi: due conferenze sulla cultura nel semestre di presidenza lettone dell'Unione Europea. Il Giornale delle Fondazioni, http://www.ilgiornaledellefondazioni.com/

Sacco PL, Segre G (2009) Creativity, cultural investment and local development: A new theoretical framework for endogenous growth. In: Fratesi U, Senn L (eds), Growth and Innovation of Competitive Regions. Berlin-Heidelberg, Springer-Verlag

Sanchez MJ, Lafuente R (2010) Defining and measuring environmental consciousness. Revista Internacional de Sociologia 68[3]: 731-755. CrossRef.

Santagata W (2009) Libro Bianco sulla Creatività. Per un Modello Italiano di Sviluppo. Università Bocconi Editore, Milano, Italy

Schliwa GI (2013) Exploring living labs through transition management. challenges and opportunities for sustainable urban transitions. Masterthesis, Lund University, Lund, Sweden

Szreter S, Woolcock M (2004) Health by association? social capital, social theory, and the political economy of public health. International Journal of Epidemiology 33[4]: $650-667$

Tempesta T (2009) Economia del paesaggio. In: Boggia A, Festa A (eds), La valutazione del danno ambientale e paesaggistico. Villa Umbra-Regione Umbria, Perugia

Trione A (1996) Estetica e Novecento. Laterza, Bari

Törnqvist G (1983) Creativity and the renewal of regional life. In: Buttimer A (ed), Creativity and Context: A Seminar Report. Gleerup, Lund, 91-112

Tveit MS, Sang AO (2014) Landscape assessment in metropolitan areas-developing a visual indicator-based approach. SPOOL 1[1]: 301-316

UNCTAD (2008) Creative economy report. http://unctad.org/en/docs/ditc20082cer_en.pdf

UNESCO (1962) Recommendation concerning the safeguarding of beauty and character of landscapes and sites. http://portal.unesco.org/en/ev.php-URL_ID=13067\&URL_DO=DO_TOPIC\&URL_SECTION=201.html 
UNESCO (2011) Recommendation on the historic urban landscape. UNESCO World Heritage Centre, Resolution 36C/23, Annex, Paris, France

United Nations (2015) Transforming our world: the 2030 agenda for sustainable development. sustainabledevelopment.un.org

Viola S (2012) Nuove sfide per le città antiche. Liguori Editore, Napoli

Viola S, Pinto MR, Cecere AM (2014) Recovering ancient settlements: Approaches to negotiation for collective spaces. Proceedings of 40th IAHS World Congress on Housing, Sustainable Housing Construction, Funchal, Madeira, Portugal

WTO - World Tourism Organization (2017) Tourism highlights 2016 edition. Madrid, UNWTO 


\section{A Appendix}

Table A.1: Relational indicators

\begin{tabular}{|c|c|c|}
\hline indicators & contents & source \\
\hline \multicolumn{3}{|c|}{ actions on built environment } \\
\hline $\begin{array}{l}\text { Cleanes of public } \\
\text { space }\end{array}$ & Washing and sweeping of public space & Campos, Oliveira (2016) \\
\hline Care of public space & $\begin{array}{l}\text { Maintenance, recovery and management of } \\
\text { public space (i.e. conservation of materials of } \\
\text { sidewalks, decks, flowerbed, street furniture) }\end{array}$ & Campos, Oliveira (2016) \\
\hline $\begin{array}{l}\text { Care of public space } \\
\text { by citizens }\end{array}$ & $\begin{array}{l}\text { Maintenance, recovery and management of } \\
\text { public space by citizens }\end{array}$ & $\begin{array}{l}\text { Revised from Campos, } \\
\text { Oliveira (2016) }\end{array}$ \\
\hline $\begin{array}{l}\text { Care of private } \\
\text { buildings }\end{array}$ & Maintenance and recovery of existing buildings & $\begin{array}{l}\text { Revised from Campos, } \\
\text { Oliveira (2016), Lynch, } \\
\text { Mosbah (2017) }\end{array}$ \\
\hline Personalization signs & $\begin{array}{l}\text { Family names, initials, ornaments on private } \\
\text { buildings }\end{array}$ & Brown, Perkins (2001) \\
\hline Use of buildings & Rate of buildings occupacy & $\begin{array}{l}\text { Revised from Ipsos MORI } \\
(2015)\end{array}$ \\
\hline $\begin{array}{l}\text { Reuse of historical } \\
\text { buildings }\end{array}$ & Rate of project of building reuse & $\begin{array}{l}\text { Revised from Ipsos MORI } \\
(2015)\end{array}$ \\
\hline $\begin{array}{l}\text { Art production } \\
\text { site-specific }\end{array}$ & $\begin{array}{l}\text { Number of artworks locally produced and } \\
\text { destined to remain in situ }\end{array}$ & $\begin{array}{l}\text { Revised from Tveit, Sang } \\
\text { (2014) }\end{array}$ \\
\hline Public art & Integration of art in public space & new \\
\hline $\begin{array}{l}\text { Art and culture in } \\
\text { public space }\end{array}$ & $\begin{array}{l}\text { Rate of use of public space for artistic and } \\
\text { cultural activities }\end{array}$ & new \\
\hline $\begin{array}{l}\text { Pro-environmental } \\
\text { behaviours - water }\end{array}$ & $\begin{array}{l}\text { Rate of use of recycling and saving water } \\
\text { systems }\end{array}$ & $\begin{array}{l}\text { Revised from Lynch, } \\
\text { Mosbah (2017) }\end{array}$ \\
\hline $\begin{array}{l}\text { Pro-environmental } \\
\text { behaviours - energy }\end{array}$ & Rate of use of renewable energy systems & $\begin{array}{l}\text { Revised from Lynch, } \\
\text { Mosbah (2017) }\end{array}$ \\
\hline $\begin{array}{l}\text { Bioclimatic design } \\
\text { solutions }\end{array}$ & Rate of use of bioclimatic design solutions & $\begin{array}{l}\text { Revised from Lynch, } \\
\text { Mosbah (2017) }\end{array}$ \\
\hline $\begin{array}{l}\text { Use of local } \\
\text { materials }\end{array}$ & Percentage of local materials and technologies & new \\
\hline $\begin{array}{l}\text { Innovation of local } \\
\text { and traditional } \\
\text { technologies }\end{array}$ & $\begin{array}{l}\text { Rate of innovation of local and traditional } \\
\text { technologies }\end{array}$ & new \\
\hline Care of the future & Strategic plans for long-term & $\begin{array}{l}\text { Fusco Girard, Torrieri } \\
(2009)\end{array}$ \\
\hline \multicolumn{3}{|c|}{ Relations between physical attributes of built environment } \\
\hline Walkability Indices & $\begin{array}{l}\text { Number of walking routes with a high } \\
\text { walkability score / number of all walking routes } \\
\text { (\%) }\end{array}$ & Paine, Thompson (2016) \\
\hline WalkScore & Rating 1-100 describing easy access to places & Paine, Thompson (2016) \\
\hline $\begin{array}{l}\text { Design of building } \\
\text { frontages fostering } \\
\text { incidental contact }\end{array}$ & $\begin{array}{l}\% \text { dwellings fronting streets or walkways that } \\
\text { include opportunities for contact with } \\
\text { passers-by (eg. seats on a porch, open windows } \\
\text { to living areas) }\end{array}$ & Paine, Thompson (2016) \\
\hline $\begin{array}{l}\text { Design of common } \\
\text { areas in buildings } \\
\text { fostering incidental } \\
\text { contact }\end{array}$ & $\begin{array}{l}\% \text { common areas that include spaces with seats } \\
\text { and/or to otherwise linger and talk with } \\
\text { neighbours }\end{array}$ & Paine, Thompson (2016) \\
\hline $\begin{array}{l}\text { Public space } \\
\text { accessible to the } \\
\text { community }\end{array}$ & $\begin{array}{l}\% \text { of open space available with unrestricted } \\
\text { access }\end{array}$ & $\begin{array}{l}\text { Paine, Thompson (2016), } \\
\text { Fusco Girard, Torrieri } \\
\text { (2009) }\end{array}$ \\
\hline $\begin{array}{l}\text { Contact with nature } \\
\text { in public space }\end{array}$ & $\begin{array}{l}\text { Area of public open space including vegetation } \\
\text { and/or water / area of all public open space (\%) }\end{array}$ & Paine, Thompson (2016) \\
\hline $\begin{array}{l}\text { Contact with nature } \\
\text { in public space }\end{array}$ & $\begin{array}{l}\text { Length of streets containing tree plantings: } \\
\text { length of all streets }(\%)\end{array}$ & Paine, Thompson (2016) \\
\hline
\end{tabular}


Table A.1 - continued from previous page

\begin{tabular}{|c|c|}
\hline indicators & contents \\
\hline $\begin{array}{l}\text { Consistency of the } \\
\text { historic urban fabric }\end{array}$ & $\begin{array}{l}\text { Share inhabited buildings constructed before } \\
1919 \text { and in excellent or good condition than the } \\
\text { total of the buildings. }\end{array}$ \\
\hline Cultural heritage & $\begin{array}{l}\text { Number of archaeological, architectural and } \\
\text { museum surveyed in the information system } \\
\text { "Risk Map of Cultural Heritage" (MiBAC) per } \\
\text { sq km }\end{array}$ \\
\hline $\begin{array}{l}\text { Public expenditure } \\
\text { on cultural heritage }\end{array}$ & $\begin{array}{l}\text { Municipal government spending allocated to } \\
\text { functions related to the culture and to the } \\
\text { goods per capita. }\end{array}$ \\
\hline \multicolumn{2}{|c|}{ Influence of built environment on people } \\
\hline $\begin{array}{l}\text { Participation in } \\
\text { lifelong learning }\end{array}$ & $\begin{array}{l}\text { People aged } 25-64 \text { who participated in education } \\
\text { (formal education) and training (non-formal } \\
\text { education) / population aged } 25-64 * 100\end{array}$ \\
\hline $\begin{array}{l}\text { People with at least } \\
\text { upper secondary } \\
\text { education }\end{array}$ & $\begin{array}{l}\text { Percentage of people aged } 25-64 \text { years having } \\
\text { completed at least upper secondary education } \\
\text { on total people aged } 25-64 \text { years. }\end{array}$ \\
\hline Level of literacy & $\begin{array}{l}\text { Scores obtained in the tests of functional } \\
\text { literacy skills of students in the } 2 \text { nd class of } \\
\text { upper secondary education }\end{array}$ \\
\hline Level of numeracy & $\begin{array}{l}\text { Scores obtained in the tests of numeracy skills } \\
\text { of students in the II classes of upper secondary } \\
\text { education }\end{array}$ \\
\hline $\begin{array}{l}\text { People with high } \\
\text { level of ICT } \\
\text { competencies }\end{array}$ & $\begin{array}{l}\text { Percentage of people aged } 16 \text { years and over } \\
\text { who can perform at least } 5 \text { over the } 6 \text { listed } \\
\text { operations on the computer on total people } \\
\text { aged } 16 \text { years and over. }\end{array}$ \\
\hline $\begin{array}{l}\text { Specialization in the } \\
\text { high knowledge } \\
\text { intensity }\end{array}$ & $\begin{array}{l}\text { Employed in high-tech manufacturing sectors } \\
\text { and those of services to knowledge intensive / } \\
\text { total employees } * 100 \text {. }\end{array}$ \\
\hline $\begin{array}{l}\text { Life expectancy at } \\
\text { birth }\end{array}$ & $\begin{array}{l}\text { Life expectancy expresses the average number of } \\
\text { years that a child born in a given calendar year } \\
\text { can expect to live if exposed during his whole } \\
\text { life to the risks of death observed in the same } \\
\text { year at different ages }\end{array}$ \\
\hline $\begin{array}{l}\text { Healthy life } \\
\text { expectancy at birth }\end{array}$ & $\begin{array}{l}\text { Average number of years that a child born in a } \\
\text { given calendar year can expect to live in good } \\
\text { health on the assumption that the risks of death } \\
\text { and perceived health conditions remain constant }\end{array}$ \\
\hline $\begin{array}{l}\text { Age-standardised } \\
\text { cancer mortality rate } \\
\text { (19-64 years old }\end{array}$ & $\begin{array}{l}\text { Mortality rate for cancer (initial cause) by five } \\
\text { year age groups for people aged } 19-64 \text { years, } \\
\text { standardized by the Italian } 2001 \text { Census } \\
\text { population of the same age groups. }\end{array}$ \\
\hline $\begin{array}{l}\text { Age-standardised } \\
\text { mortality rate for } \\
\text { dementia and related } \\
\text { illnesses (people } \\
\text { aged } 65 \text { and over) }\end{array}$ & $\begin{array}{l}\text { Mortality rate for nervous system diseases and } \\
\text { psychical and behavioural disorders (initial } \\
\text { cause) by five year age groups for people aged } \\
65 \text { years and over, standardized by the Italian } \\
2001 \text { Census population of the same age groups. }\end{array}$ \\
\hline $\begin{array}{l}\text { Life expectancy } \\
\text { without activity } \\
\text { limitations at } 65 \\
\text { years of age }\end{array}$ & $\begin{array}{l}\text { Average number of years that a person aged } 65 \\
\text { can expect to live without suffering limitations } \\
\text { in daily activities due to health problems, } \\
\text { assuming that the risks of death and disability } \\
\text { remain constant over time and equal to those } \\
\text { observed in a specific calendar year }\end{array}$ \\
\hline
\end{tabular}


Table A.1 - continued from previous page

\begin{tabular}{ll}
\hline indicators & contents \\
\hline Cultural & Synthetic indicator of the level of cultural \\
participation & participation based on the aggregation of the \\
& vollowing indicators: People who have seen \\
& Percentages or DVDs in the past 12 months; \\
& the interview have traveled at least once in \\
& Cinema, Theatre, Museums and exhibitions, \\
& archaeological sites, monuments, concerts \\
& (classical music, opera + Other music concerts); \\
& Reading: Percentage of people who read the \\
& newspaper at least once a week; Percentage of \\
& people who have read at least one book in the \\
& 12 months preceding the interview; Percentage \\
& of people who read a magazine regularly (weekly \\
& or periodic) \\
& Disadvantaged persons involved
\end{tabular}

disadvantaged

people

Incidence of

knowledge workers

on employment

Employers with college education (ISCED 5-6)

in professions Scientific Technology (ISCO 2-3) /

Total employed * 100 .

Social participation Based on the aggregation of the following

indicators: a) People aged 14 and over who during the last 12 months have participated in meetings of associations (cultural / recreational, ecological, civil rights, for peace); b) People aged 14 and over who during the last 12 months have participated in meetings of trade unions, professional associations or category; c) People aged 14 and over who during the last 12 months have participated in meetings of political parties and / or have worked free for a party d) People aged 14 and over who pay a monthly fee to a club or periodic / sports club e) People aged 14 and over in the last 12 months took part in meetings or initiatives (cultural, sporting, recreational, spiritual) made or promoted by parishes, organizations / religious groups or spiritual

Civic and political participation

Based on the aggregation of the following indicators: 1) People aged 14 and over who talk source BES_Istat (2.11) about politics at least once a week 2) People aged 14 and over who inform policy at least once a week 3) People aged 14 and over who participated in online consultations or voting on social issues (civic) or political (eg. Urban planning, signing a petition) in the last 3 months 4) People aged 14 and over who have read and posted opinions on social or political problems on the web over the past 3 months

Voluntary activities People aged 14 and over in the last 12 months worked free for associations or voluntary groups / People aged 14 and over * 100

Local Percentage of people involved in local community activities over the past two years

commity-people Percentage of people involved in public meeting community-people (rather than in the workplace) in the last year

\section{internal relationships of heritage community}

Local communityfoundations

Local communityart and culture

Local communityhobby
Average number of foundations, associations and public organizations per 10,000 inhabitants Average number of members of the arts, music and other cultural groups for 10,000 inhabitants Average number of members of interest groups and hobby for 10,000 inhabitants
Dzialek (2014)

Dzialek (2014)

Dzialek (2014) 
Table A.1 - continued from previous page

\begin{tabular}{|c|c|c|}
\hline indicators & contents & source \\
\hline $\begin{array}{l}\text { Local community- } \\
\text { sport }\end{array}$ & $\begin{array}{l}\text { Average number of members of sports and } \\
\text { recreational groups for } 10,000 \text { inhabitants }\end{array}$ & Dzialek (2014) \\
\hline NGOs & $\begin{array}{l}\text { Number of non-governmental organizations } \\
\text { registered for } 10,000 \text { inhabitants }\end{array}$ & Dzialek (2014) \\
\hline $\begin{array}{l}\text { Charitable } \\
\text { Organizations }\end{array}$ & $\begin{array}{l}\text { Number of public charities for } 10,000 \\
\text { inhabitants }\end{array}$ & Dzialek (2014) \\
\hline $\begin{array}{l}\text { Religious } \\
\text { organizations }\end{array}$ & Member of religious organizations and church & Dzialek (2014) \\
\hline $\begin{array}{l}\text { Religious } \\
\text { organizations }\end{array}$ & $\begin{array}{l}\text { Members of organizations, associations, parties, } \\
\text { committees advise, religious groups, unions and } \\
\text { other groups to } 100 \text { people }\end{array}$ & Dzialek (2014) \\
\hline $\begin{array}{l}\text { No profit } \\
\text { organizations per } \\
10,000 \text { inhabitants }\end{array}$ & $\begin{array}{l}\text { Number of non-profit organizations / total } \\
\text { population } * 10,000\end{array}$ & BES_Istat (5.9) \\
\hline $\begin{array}{l}\text { Social cooperatives } \\
\text { every } 10,000 \\
\text { inhabitants }\end{array}$ & $\begin{array}{l}\text { Number of social cooperatives / total } \\
\text { population * } 10,000\end{array}$ & BES_Istat (5.10) \\
\hline Coworking activities & $\begin{array}{l}\text { Number of activities and businesses housed in } \\
\text { coworking }\end{array}$ & new \\
\hline Number of networks & Number of networked production activities & new \\
\hline \multicolumn{3}{|c|}{ Relationships between landscape and external environment } \\
\hline $\begin{array}{l}\text { Intensity of use of } \\
\text { the internet }\end{array}$ & $\begin{array}{l}\text { People } 16-74 \text { years who used the internet at } \\
\text { least once a week over the } 12 \text { months preceding } \\
\text { the interview / persons of } 16-74 \text { years } * 100\end{array}$ & BES_Istat (11.7) \\
\hline Numbers of start-up & Number of start-ups / total enterprises & Greffe \\
\hline Research intensity & Spending on R\&S/GDP *100 (Ocse). & BES_Istat (11.1) \\
\hline $\begin{array}{l}\text { Propensity for } \\
\text { patenting }\end{array}$ & $\begin{array}{l}\text { Total number of patent applications the } \\
\text { European Patent Office (EPO) per million } \\
\text { inhabitants }\end{array}$ & BES_Istat (11.2) \\
\hline $\begin{array}{l}\text { Rate of technological } \\
\text { innovation in the } \\
\text { production system }\end{array}$ & $\begin{array}{l}\text { Companies that have introduced technological } \\
\text { innovations (product and process), } \\
\text { organizational and marketing in the three-year } \\
\text { period / total number of companies with at } \\
\text { least } 10 \text { employees * } 100\end{array}$ & BES_Istat (11.4) \\
\hline $\begin{array}{l}\text { Rate of innovation of } \\
\text { the product / service } \\
\text { of the national } \\
\text { production system }\end{array}$ & $\begin{array}{l}\text { Companies that have introduced product } \\
\text { innovations-service over three years / Total } \\
\text { Companies with at least } 10 \text { employees * } 100\end{array}$ & BES_Istat (11.5) \\
\hline $\begin{array}{l}\text { Contemporary art } \\
\text { production to a } \\
\text { foreign market }\end{array}$ & $\begin{array}{l}\text { Number of works of art produced on-siteand } \\
\text { destined to the external market }\end{array}$ & $\begin{array}{l}\text { Fusco Girard, Torrieri } \\
(2009)\end{array}$ \\
\hline $\begin{array}{l}\text { Cultural and } \\
\text { creative industries } \\
\text { production }\end{array}$ & $\begin{array}{l}\text { Number of cultural and creative industries } \\
\text { production }\end{array}$ & $\begin{array}{l}\text { Revised from Fusco } \\
\text { Girard, Torrieri (2009) }\end{array}$ \\
\hline New residents & $\begin{array}{l}\text { number of people who decide to live and } \\
\text { develop their own projects in a place (young) }\end{array}$ & Greffe \\
\hline Tourists and visitors & Number of tourists and visitors & Greffe \\
\hline $\begin{array}{l}\text { Exchanges tourists / } \\
\text { local community }\end{array}$ & $\begin{array}{l}\text { Events involving the interaction between } \\
\text { tourists and locals }\end{array}$ & new \\
\hline $\begin{array}{l}\text { Exchanges artists / } \\
\text { community }\end{array}$ & $\begin{array}{l}\text { Events involving the interaction between artists } \\
\text { and locals }\end{array}$ & new \\
\hline Web exposure & Number of results available on google & new \\
\hline $\begin{array}{l}\text { Popularity index } \\
\text { web }\end{array}$ & $\begin{array}{l}\text { number of groups like facebook, approval rating } \\
\text { on tripadvisor, foursquare, etc .. }\end{array}$ & new \\
\hline Prizes and Awards & Number of awards granted in the last five years & new \\
\hline
\end{tabular}




\section{B Appendix}

Table B.2: Existing relationships in Torre Annunziata

\begin{tabular}{|c|c|c|c|c|c|c|c|c|}
\hline indicators & source & $\begin{array}{l}\text { metro- } \\
\text { area of } \\
\text { Napoli }\end{array}$ & $\begin{array}{l}\text { Napoli } \\
\text { munici- } \\
\text { pality }\end{array}$ & $\begin{array}{l}\text { munici- } \\
\text { pality }\end{array}$ & $\begin{array}{l}\text { census } \\
\text { area }\end{array}$ & district & year & $\begin{array}{l}\text { positive } \\
\text { direc- } \\
\text { tion }\end{array}$ \\
\hline \multicolumn{9}{|c|}{ Actions on built environment } \\
\hline $\begin{array}{l}\text { Residential buildings } \\
\text { in mediocre or poor } \\
\text { condition }\end{array}$ & $\begin{array}{l}\text { ISTAT } \\
\text { Ottomila } \\
\text { census }\end{array}$ & & & & 459 & 124 & 2011 & $\min$ \\
\hline $\begin{array}{l}\text { Rate of buildings in } \\
\text { poor condition }\end{array}$ & $\begin{array}{l}\text { ISTAT } \\
\text { Ottomila } \\
\text { census }\end{array}$ & & & 0,3 & 0,7 & & 2011 & $\min$ \\
\hline $\begin{array}{l}\text { Rate of buildings in } \\
\text { good conservation } \\
\text { status }\end{array}$ & $\begin{array}{l}\text { ISTAT } \\
\text { Ottomila } \\
\text { census }\end{array}$ & & & 79.8 & 59.2 & & 2011 & $\max$ \\
\hline $\begin{array}{l}\text { Index of building } \\
\text { degradation }\end{array}$ & ISTAT & & & 0.2 & & & 2011 & $\min$ \\
\hline $\begin{array}{l}\text { Consistency of } \\
\text { occupied historical } \\
\text { homes }\end{array}$ & $\begin{array}{l}\text { ISTAT } \\
\text { Ottomila } \\
\text { census }\end{array}$ & & & 22.5 & 41.1 & & 2011 & $\max$ \\
\hline Use of buildings & $\begin{array}{l}\text { ISTAT } \\
\text { Ottomila } \\
\text { census }\end{array}$ & & & $3.1 \%$ & $10.1 \%$ & & 2011 & $\min$ \\
\hline $\begin{array}{l}\text { Cleanes of public space } \\
\text { (rate 1-5) }\end{array}$ & $\begin{array}{l}\text { on-site } \\
\text { analysis }\end{array}$ & & & & 1 & & 2016 & $\max$ \\
\hline $\begin{array}{l}\text { Art production } \\
\text { site-specific }\end{array}$ & $\begin{array}{l}\text { on-site } \\
\text { analysis }\end{array}$ & & & & 0 & & 2016 & $\max$ \\
\hline Public art & $\begin{array}{l}\text { on-site } \\
\text { analysis }\end{array}$ & & & & 0 & & 2016 & $\max$ \\
\hline $\begin{array}{l}\text { Art and culture in } \\
\text { public space }\end{array}$ & $\begin{array}{l}\text { on-site } \\
\text { analysis }\end{array}$ & & & & 0 & & 2016 & $\max$ \\
\hline $\begin{array}{l}\text { Annual municipal } \\
\text { electricity production } \\
\text { from renewable sources } \\
\text { (photovoltaic) }\end{array}$ & GSE & & & 277.91 & & & 2016 & $\max$ \\
\hline $\begin{array}{l}\text { Annual municipal } \\
\text { electricity production } \\
\text { from renewable sources } \\
\text { (photovoltaic) }\end{array}$ & ispra & & & 0.59 & & & 2014 & $\max$ \\
\hline \multicolumn{9}{|c|}{ Relations between physical attributes of built environment } \\
\hline WalkScore & $\begin{array}{l}\text { www.- } \\
\text { walk- } \\
\text { score.- } \\
\text { com }\end{array}$ & & & & & 78 & 2017 & $\max$ \\
\hline $\begin{array}{l}\text { Design of building; } \\
\text { frontages fostering } \\
\text { incidental contact }(\%)\end{array}$ & $\begin{array}{l}\text { on-site } \\
\text { analysis }\end{array}$ & & & & & 80 & 2015 & $\max$ \\
\hline $\begin{array}{l}\text { Public space accessible } \\
\text { to the community }\end{array}$ & $\begin{array}{l}\text { on-site } \\
\text { analysis }\end{array}$ & & & & & 0 & 2015 & $\max$ \\
\hline $\begin{array}{l}\text { Public green spaces } \\
\text { rate }\end{array}$ & SIT & & & 0.32 & & & 2011 & $\max$ \\
\hline $\begin{array}{l}\text { Contact with nature in } \\
\text { public space (1) }\end{array}$ & $\begin{array}{l}\text { on-site } \\
\text { analysis }\end{array}$ & & & & & 0 & 2016 & $\max$ \\
\hline $\begin{array}{l}\text { Contact with nature in } \\
\text { public space }(2)\end{array}$ & $\begin{array}{l}\text { on-site } \\
\text { analysis }\end{array}$ & & & & & 0 & 2016 & $\max$ \\
\hline $\begin{array}{l}\text { Consistency of the } \\
\text { historic urban fabric }\end{array}$ & $\begin{array}{l}\text { ISTAT } \\
\text { BES }\end{array}$ & 38.2 & & & & & 2011 & $\max$ \\
\hline $\begin{array}{l}\text { Rate of urban areas } \\
\text { with protection } \\
\text { constraints }\end{array}$ & MIBACT & & & & & 1 & 2011 & $\max$ \\
\hline
\end{tabular}


Table B.2 - continued from previous page

\begin{tabular}{|c|c|c|c|c|c|c|c|}
\hline indicators & source & $\begin{array}{l}\text { metro- } \\
\text { area of } \\
\text { Napoli }\end{array}$ & $\begin{array}{l}\text { Napoli } \\
\text { munici- } \\
\text { pality }\end{array}$ & $\begin{array}{l}\text { munici- } \\
\text { pality }\end{array}$ & $\begin{array}{l}\text { census district } \\
\text { area }\end{array}$ & year & $\begin{array}{l}\text { positive } \\
\text { direc- } \\
\text { tion }\end{array}$ \\
\hline Cultural heritage & $\begin{array}{l}\text { ISTAT } \\
\text { BES }\end{array}$ & & & 1 & & 2011 & $\max$ \\
\hline \multicolumn{8}{|c|}{ Influence of built environment on people } \\
\hline $\begin{array}{l}\text { Participation in } \\
\text { lifelong learning }\end{array}$ & $\begin{array}{l}\text { ISTAT } \\
\text { Ottomila } \\
\text { census }\end{array}$ & & & 4.4 & & 2011 & $\max$ \\
\hline $\begin{array}{l}\text { Rate of adults with } \\
\text { high school diploma or } \\
\text { degree }\end{array}$ & $\begin{array}{l}\text { ISTAT } \\
\text { Ottomila } \\
\text { census }\end{array}$ & & & 48.6 & 39.1 & 2011 & $\max$ \\
\hline $\begin{array}{l}\text { Rate of young people } \\
\text { with university } \\
\text { education }\end{array}$ & $\begin{array}{l}\text { ISTAT } \\
\text { Ottomila } \\
\text { census }\end{array}$ & & & 18.1 & 12.2 & 2011 & $\max$ \\
\hline Level of literacy & $\begin{array}{l}\text { ISTAT } \\
\text { BES }\end{array}$ & & 190 & & & 2014 & $\max$ \\
\hline Level of numeracy & $\begin{array}{l}\text { ISTAT } \\
\text { BES }\end{array}$ & & 191.3 & & & 2014 & $\max$ \\
\hline $\begin{array}{l}\text { Specialization in the } \\
\text { high knowledge } \\
\text { intensity }\end{array}$ & $\begin{array}{l}\text { ISTAT } \\
\text { Ottomila } \\
\text { census }\end{array}$ & & & 32.1 & 26.4 & 2011 & $\max$ \\
\hline $\begin{array}{l}\text { Incidence of people not } \\
\text { engaged in education, } \\
\text { employment or } \\
\text { training (NEET) }\end{array}$ & $\begin{array}{l}\text { ISTAT } \\
\text { Ottomila } \\
\text { census }\end{array}$ & & & 24.8 & 32.7 & 2011 & $\min$ \\
\hline $\begin{array}{l}\text { Life expectancy at } \\
\text { birth (men) }\end{array}$ & $\begin{array}{l}\text { ISTAT } \\
\text { BES }\end{array}$ & & 77.6 & & & 2013 & $\max$ \\
\hline $\begin{array}{l}\text { Life expectancy at } \\
\text { birth (women) }\end{array}$ & $\begin{array}{l}\text { ISTAT } \\
\text { BES }\end{array}$ & & 82.4 & & & 2013 & $\max$ \\
\hline $\begin{array}{l}\text { Age-standardised } \\
\text { cancer mortality rate } \\
\text { (19-64 years old }\end{array}$ & $\begin{array}{l}\text { ISTAT } \\
\text { BES }\end{array}$ & & 11.1 & & & 2013 & $\min$ \\
\hline $\begin{array}{l}\text { Age-standardised } \\
\text { mortality rate for } \\
\text { dementia and related } \\
\text { illnesses (people aged } \\
65 \text { and over) }\end{array}$ & $\begin{array}{l}\text { ISTAT } \\
\text { BES }\end{array}$ & & 21.5 & & & 2013 & $\min$ \\
\hline $\begin{array}{l}\text { Participation rate in } \\
\text { European elections }\end{array}$ & $\begin{array}{l}\text { ISTAT } \\
\text { BES }\end{array}$ & & 48.5 & & & 2014 & $\max$ \\
\hline $\begin{array}{l}\text { Participation rate in } \\
\text { regional elections }\end{array}$ & $\begin{array}{l}\text { ISTAT } \\
\text { BES }\end{array}$ & & 61.2 & & & 2010 & $\max$ \\
\hline $\begin{array}{l}\text { Volunteers rate per } 100 \\
\text { inhabitants aged } 14 \\
\text { and over }(\%)\end{array}$ & $\begin{array}{l}\text { ISTAT } \\
\text { BES }\end{array}$ & & 3 & & & 2011 & $\max$ \\
\hline Non-profit employees & ISTAT & & & 87 & & 2011 & $\max$ \\
\hline \multicolumn{8}{|c|}{ Internal relationships of heritage community } \\
\hline $\begin{array}{l}\text { Social cooperatives } \\
\text { every } 10,000 \\
\text { inhabitants }\end{array}$ & $\begin{array}{l}\text { ISTAT } \\
\text { BES }\end{array}$ & & 1.3 & & & 2011 & $\max$ \\
\hline $\begin{array}{l}\text { No profit organizations } \\
\text { per } 10,000 \text { inhabitants }\end{array}$ & $\begin{array}{l}\text { ISTAT } \\
\text { BES }\end{array}$ & & 18.2 & & & 2011 & $\max$ \\
\hline \multicolumn{8}{|c|}{ Relationships between landscape and external environment } \\
\hline $\begin{array}{l}\text { Propensity for } \\
\text { patenting (per } 1 \\
\text { million of inhabitants) }\end{array}$ & $\begin{array}{l}\text { ISTAT } \\
\text { BES }\end{array}$ & & 14.5 & & & 2012 & $\max$ \\
\hline $\begin{array}{l}\text { Patent impact in the } \\
\text { High-tech sector }(\%)\end{array}$ & $\begin{array}{l}\text { ISTAT } \\
\text { BES }\end{array}$ & & 23.9 & & & 2012 & $\max$ \\
\hline $\begin{array}{l}\text { Patent impact in the } \\
\text { ICT sector }(\%)\end{array}$ & $\begin{array}{l}\text { ISTAT } \\
\text { BES }\end{array}$ & & 24.6 & & & 2012 & $\max$ \\
\hline
\end{tabular}


Table B.2 - continued from previous page

\begin{tabular}{|c|c|c|c|c|c|c|c|c|}
\hline indicators & source & $\begin{array}{l}\text { metro- } \\
\text { area of } \\
\text { Napoli }\end{array}$ & $\begin{array}{l}\text { Napoli } \\
\text { munici- } \\
\text { pality }\end{array}$ & $\begin{array}{l}\text { munici- } \\
\text { pality }\end{array}$ & $\begin{array}{l}\text { census } \\
\text { area }\end{array}$ & district & year & $\begin{array}{l}\text { positive } \\
\text { direc- } \\
\text { tion }\end{array}$ \\
\hline $\begin{array}{l}\text { Patent impact in } \\
\text { biotechnology sector } \\
(\%)\end{array}$ & $\begin{array}{l}\text { ISTAT } \\
\text { BES }\end{array}$ & & 20.2 & & & & 2012 & $\max$ \\
\hline $\begin{array}{l}\text { Contemporary art } \\
\text { production to a foreign } \\
\text { market }\end{array}$ & $\begin{array}{l}\text { on-site } \\
\text { analysis }\end{array}$ & & & & & 0 & 2015 & $\max$ \\
\hline $\begin{array}{l}\text { High quality } \\
\text { production to a foreign } \\
\text { market }\end{array}$ & $\begin{array}{l}\text { on-site } \\
\text { analysis }\end{array}$ & & & & & 1 & 2015 & $\max$ \\
\hline $\begin{array}{l}\text { Demographic variation } \\
2011-2001\end{array}$ & $\begin{array}{l}\text { ISTAT } \\
\text { Ottomila } \\
\text { census }\end{array}$ & & & -4490 & & & 2011 & $\min$ \\
\hline Travel reviews & $\begin{array}{l}\text { Trip } \\
\text { Advisor }\end{array}$ & & & 1097 & & 0 & 2017 & $\max$ \\
\hline Things to do & $\begin{array}{l}\text { Trip } \\
\text { Advisor }\end{array}$ & & & 33 & & 0 & 2017 & $\max$ \\
\hline
\end{tabular}

